\title{
Thoridae (Crustacea: Decapoda) can penetrate the Abyss: a new species of Lebbeus from the Sea of Okhotsk, representing the deepest record of the family
}

\author{
Ivan MARIN \\ A.N. Severtzov Institute of Ecology and Evolution, Russian Academy of Sciences, Moscow, Russia. \\ Email: coralliodecapoda@mail.ru,vanomarin@yahoo.com \\ urn:Isid:zoobank.org:author:B26ADAA5-5DBE-42B3-9784-3BC362540034
}

\begin{abstract}
Lebbeus sokhobio sp. nov. is described from abyssal depths (3303-3366 m) in the Kuril Basin of the Sea of Okhotsk. The related congeners are deep-water dwellers with a very distant distribution and very similar morphology. The new species is separated by minor morphological features, such as the armature of the rostrum and telson, meral spinulation of ambulatory pereiopods and the shape of the pleonal pleurae. This species is the deepest dwelling representative of the genus Lebbeus and the family Thoridae. A list of records of caridean shrimps recorded from abyssal depths below $3000 \mathrm{~m}$ is given.
\end{abstract}

Keywords. Diversity, Caridea, barcoding, SokhoBio 2015, NW Pacific.

Marin I. 2020. Thoridae (Crustacea: Decapoda) can penetrate the Abyss: a new species of Lebbeus from the Sea of Okhotsk, representing the deepest record of the family. European Journal of Taxonomy 604: 1-35.

https://doi.org/10.5852/ejt.2020.604

\section{Introduction}

The fauna of benthic caridean shrimps (Crustacea: Decapoda: Caridea) living at depths of more than $3000 \mathrm{~m}$ is poorly known due to the technical difficulties of sampling. There are many records of caridean shrimps from the abyssal depths, but it is still expected that deeper sampling in different regions of the world oceans will provide new records and interesting scientific data. The deepest known records of caridean shrimps are Parapontophilus abyssi (Smith, 1884) (Crangonidae), collected from a depth of $5852 \mathrm{~m}$ (Chace 1984), Glyphocrangon atlantica Chace, 1939 (Glyphocrangonidae) from 6364-6373 m (Holthuis 1971; Gore 1985), and the bathypelagic Heterogenys microphthalma (Smith, 1885) and Acanthephyra sica Spence Bate, 1888 (Acanthephyridae) from $5060 \mathrm{~m}$ (Wicksten et al. 2017; Crosnier 1987) and $6890 \mathrm{~m}$ (Lörz et al. 2012), respectively. Such depths exceed the maximum available depths, for example, for cartilaginous fishes (Chondrichthyes) (4156 m; Priede \& Froese 2013), but at the same time far from the depths available to abyssal fishes such as Pseudoliparis swirei Gerringer \& Linley, 2017 (Actinopterygii: Liparidae) (6898-7966 m; Gerringer et al. 2017) and Abyssobrotula galatheae Nielsen, 1977 (Actinopterygii: Ophidiidae) ( 8370 m; Priede \& Froese 2013) or the polychaete Poecilochaetus vityazi Levenstein, 1962 (Annelida: Poecilochaetidae), collected at a depth of $10687 \mathrm{~m}$ from the Tonga Trench (Paterson et al. 2009). The deepest records of crustaceans are Macrostylis 
mariana Mezhov, 1993 (Isopoda: Macrodactylidae) and Hirondellea gigas (Birštein \& Vinogradov, 1955) (Amphipoda: Hirondelleidae), recorded from hadal depths of $10730 \mathrm{~m}$ (Mezhov 1993) and 10897-10994 m (e.g., Hessler et al. 1978; Kobayashi et al. 2012), respectively. The limiting factors for the deep-sea distribution of decapod crustaceans are still unknown due to the small number of collected samples and insufficient knowledge of the biology and ecology of such species. Wolff (1970) proposed the physiological limitation of hydrostatic pressure as a factor limiting the deeper distribution of species in Decapoda.

The deep-sea decapod fauna of the northwestern Pacific is relatively well studied (e.g., Bražhnikov 1907; Derjugin \& Kobjakova 1935; Kobjakova 1936, 1937, 1955, 1958, 1962, 1967; Makarov 1938, 1962, 1966; Vinogradov 1947, 1950; Birštein \& Vinogradov 1951, 1953; Uschakov 1953; Zarenkov 1960, 1965; Savilov 1961; Kurata 1964a, 1964b; Komai \& Amaoka 1991; Komai 1991, 1994, 1997, 2015; Komai \& Yakovlev 2000; Sedova 2004; Komai \& Komatsu 2009; Spiridonov et al. 2013; Sedova \& Andronov 2013; Sedova \& Grigoriev 2013; Marin 2013, 2018; Marin et al. 2015; Matsuzaki et al. 2015; Komai \& Matsuzaki 2016; Komai et al. 2016, 2017; Anosov et al. 2018; Komai \& Hibino 2019), while abyssal records of decapods are still rare. Only seven benthic caridean species are known from the abyssal zone (depths of 3000-6000 m) in the northwestern Pacific: Nematocarcinus longirostris Spence Bate, 1888 (Nematocarcinidae); Bathystylodactylus inflatus Hanamura \& Takeda, 1996, Bathystylodactylus cf. bathyalis (Cleva, 1994) (Stylodactylidae); Glyphocrangon caecescens Wood-Mason, 1891 (Glyphocrangonidae); Neocrangon abyssorum (Rathbun, 1902), Sclerocrangon zenkevitchii Birštein \& Vinogradov, 1953 and Placopsicrangon formosa Komai \& Chan, 2009 (Crangonidae) (Kobjakova 1937; Birštein \& Vinogradov 1953; Hanamura \& Takeda 1996; Kim et al. 2000; Burukovsky 2003; Komai 2004; Komai \& Chan 2009; Komai \& Komatsu 2016; Wicksten et al. 2017; Marin 2018). Several biological surveys were accomplished in the Kuril Basin - a relatively isolated and the deepest area of the Sea of Okhotsk (Vinogradov 1950; Birštein \& Vinogradov 1953; Ushakov 1953; Savilov 1961; review in Marin 2018). Four species of benthic decapod crustaceans have been recorded in the Sea of Okhotsk deeper than $3000 \mathrm{~m}$ : Neocrangon abyssorum from a depth of 887-2975 m and possibly below 3000 m (Birštein \& Vinogradov 1951; Zarenkov 1965; Kim et al. 2000; Marin 2018); Sclerocrangon zenkevitchi from 2995-3950 m (Birštein \& Vinogradov 1953; Kim et al. 2000; Marin 2018); an undescribed species of the genus Lebbeus White, 1847 (Thoridae) from 3303-3366 m (Marin 2018); and Munidopsis kurilensis Marin, 2020 (Munidopsidae) from 3307-3350 m (Kobjakova 1937; Marin 2018, 2020). In addition, two bathypelagic species, Hymenodora glacialis (Buchholz, 1874) and H. frontalis Rathbun, 1902 (Acanthephyridae), were recorded at depths of 3300 and $4432 \mathrm{~m}$, respectively (Kobjakova 1937; Marin 2018). Here the deep-sea species of the genus Lebbeus, previously recorded from the Kuril Basin of the Sea of Okhotsk (see Marin 2018), is described in detail as new to science.

The cosmopolitan thorid genus Lebbeus currently includes 68 valid species, representing the most species-rich genus within the family. Species of this genus are distributed from littoral to bathyal depths of both the northern and southern hemispheres (Fransen 1997; De Grave \& Fransen 2011; Komai et al. 2012, 2019; Nye et al. 2013a; Komai 2013, 2015; Schiaparelli et al. 2015; Chan \& Komai 2017). Most of the species are known as free-living, but some of them have symbiotic habits in shallow waters (e.g., Hayashi \& Okuno 1997; Jonsson et al. 2001; Schiaparelli et al. 2015) or are associated with specific deep-sea biotopes such as hydrothermal vents (Nye et al. 2013a), cold seeps (Chan \& Komai 2017) and in association with dead whale carcasses (Nye 2013). On the other hand, the geographical range of each species is rather limited, especially in deep-sea species, which leads to a high degree of endemism (e.g., Hayashi 1992; Komai et al. 2004, 2012; Komai 2015; Anosov et al. 2018); such endemic species are found in the Sea of Okhotsk (Hayashi 1992; Komai et al. 2004, 2012; see below). About half of all species of Lebbeus have been described from the northwestern Pacific, suggesting a possible radiation center of the genus in this region (Nye et al. 2013a). The Sea of Okhotsk is one of the "hot spots" of biodiversity in the genus Lebbeus with 16 described species (Bražhnikov 1907; Kobjakova 1936, 1937; 
Urita 1942; Vinogradov 1950; Zarenkov 1960; Hayashi 1992; Komai 2015; Matsuzaki et al. 2015). At least seven species, namely L. fujimotoi Matsuzaki et al., 2015, L. heterochaelus (Kobyakova, 1936), L. longidactylus (Kobyakova, 1936), L. magnificus Komai, 2015, L. spinirostris (Kobyakova, 1936), L. ushakovi (Kobyakova, 1936) and L. vinogradovi Zarenkov, 1960, have not been recorded from outside of the Sea of Okhotsk; some species are only known from their original descriptions (e.g., Anosov et al. 2018; Matsuzaki et al. 2015). Most species of Lebbeus are known from depths of less than $1500 \mathrm{~m}$ (e.g., Squires 1990; Hayashi 1992; Fransen 1997; De Grave \& Fransen 2011; Komai 2013; Nye et al. 2013a, 2013b), with the deepest dwelling being L. virentova Nye et al., 2013, recorded from a depth of 2294-2375 m in the Caribbean Sea, and L. laurentae Wicksten, 2010, recorded from a depth of 2618-2640 m at the East Pacific Rise in the northeastern Pacific (Wicksten 2010; Komai et al. 2012; Nye et al. 2013a, 2013b). The new species described here represents the deepest dwelling species within the genus and family, significantly increasing the bathymetric range of the genus to the abyssal depth of $3366 \mathrm{~m}$. Moreover, the family Thoridae is now included in the list of deepest dwelling caridean shrimp families (see Table 1).

\section{Material and methods}

The material was collected during the megafaunal sampling of the joint Russian-German SokhoBio (Sea of Okhotsk Biodiversity Study) 2015 Expedition by the R/V "Akademik M.A. Lavrentyev" in the Kuril Basin, the deepest part of the Sea of Okhotsk (see Fig. 1). Collection was made using an Agassiz Trawl (AGT) or an epibenthic sled (EBS) (see Malyutina et al. 2018). Station data for all AGT deployments are presented in Fig. 1 and also by Blagodatski et al. (2017) and Malyutina et al. (2018). Start and, sometimes, the end coordinates refer to the positions 'on ground' and 'off ground', respectively. The AGT used in the SokhoBio 2015 Expedition was of a standard design with frame dimensions (width $\times$ height) of $350 \times 70 \mathrm{~cm}$ and a mesh size of $10 \mathrm{~mm}$. In general, the AGT was deployed twice at each station; however, at some stations only one AGT was deployed. The AGT was pulled between 4 and

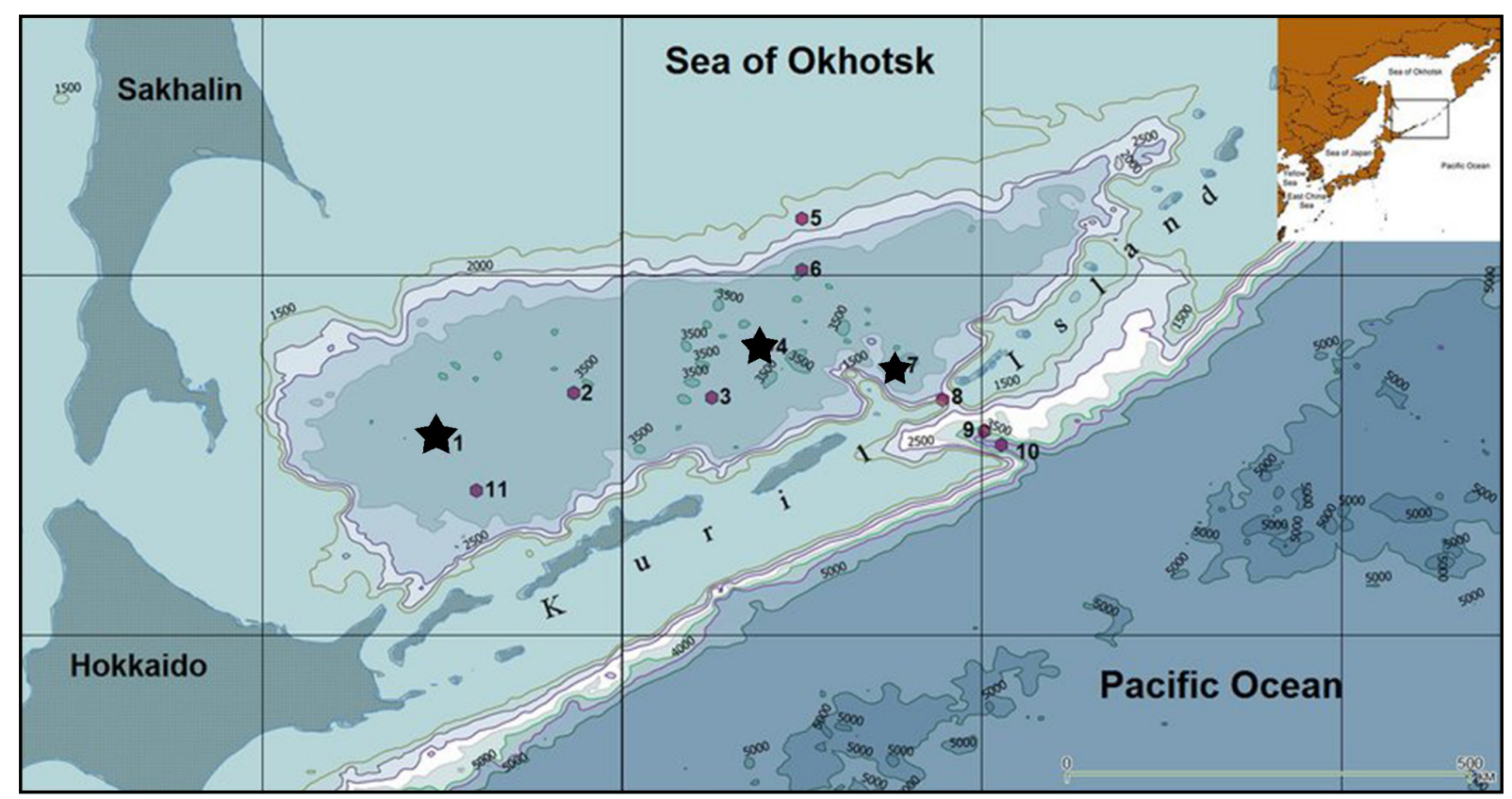

Fig. 1. Map of the stations of the SokhoBio 2015 Expedition on the R/V "Akademik M.A. Lavrentyev" in the Kuril Basin of the Sea of Okhotsk, northwestern Pacific. Insert in the upper right corner places the region of the sampling on the map of the northwestern Pacific area (after Blagodatski et al. 2017). Numbers 1-11 indicate the stations where benthic samples were collected; stars indicate the stations that yielded specimens of Lebbeus sokhobio sp. nov. 
Table 1 (continued on next 3 pages). Caridean shrimp species hitherto recorded from depths below $3000 \mathrm{~m}$.

\begin{tabular}{|c|c|c|c|}
\hline \multicolumn{3}{|c|}{ Acanthephyridae Spence Bate, 1888} & \multirow[b]{2}{*}{ Kemp 1906; Chace 1940, 1986; Allen \& Butler 1994} \\
\hline $\begin{array}{l}\text { Acanthephyra acutifrons } \\
\text { Spence Bate, } 1888\end{array}$ & $650-4926 \mathrm{~m}$ & Pacific & \\
\hline A. brevirostris Smith, 1885 & $1000-5394 \mathrm{~m}$ & N Atlantic & Smith 1885; Domansky 1986 \\
\hline $\begin{array}{c}\text { A. curtirostris } \\
\text { Wood-Mason, } 1891\end{array}$ & $190-4970 \mathrm{~m}$ & $\begin{array}{l}\text { Pacific, Indian and } \\
\text { Atlantic Oceans }\end{array}$ & $\begin{array}{c}\text { De Man 1920; Chace 1940, 1986; Crosnier \& } \\
\text { Forest 1973; Butler 1980; Krygier \& Pearcy 1981; } \\
\text { Allen \& Butler } 1994\end{array}$ \\
\hline A. eximia Smith, 1884 & $200-5111 \mathrm{~m}$ & $\begin{array}{l}\text { Pacific and } \\
\text { Atlantic; } \\
\text { Mediterranean Sea }\end{array}$ & Pohle 1992; Poupin 1996; Linley et al. 2018 \\
\hline A. pelagica (Risso, 1816) & $3635 \mathrm{~m}$ & South Ocean & $\begin{array}{c}\text { Boschi et al. 1981; Wasmer 1986; Iwasaki \& } \\
\text { Nemoto 1987; Tiefenbacher 1994; Gorny 1999; } \\
\text { Basher \& Costello } 2014\end{array}$ \\
\hline A. prionata Foxton, 1971 & $1900-4926 \mathrm{~m}$ & $\begin{array}{l}\text { Atlantic, off East } \\
\text { Africa; E Pacific }\end{array}$ & Foxton 1971; Allen \& Butler 1994 \\
\hline $\begin{array}{l}\text { A. quadrispinosa } \\
\text { Kemp, } 1939\end{array}$ & $5040-5060 \mathrm{~m}$ & Indian Ocean & Crosnier 1987 \\
\hline A. sica Spence Bate, 1888 & $400-6890 \mathrm{~m}$ & off New Zealand & Lörz et al. 2012 \\
\hline $\begin{array}{l}\text { A. stylorostratis } \\
\text { (Spence Bate, 1888) }\end{array}$ & $3458 \mathrm{~m}$ & Atlantic and Pacific & Spence Bate 1888 \\
\hline Acanthephyra spp. & $6007-6890 \mathrm{~m}$ & Pacific & Jamieson et al. 2009; Wicksten et al. 2017 \\
\hline $\begin{array}{l}\text { Heterogenys micro- } \\
\text { phthalma (Smith, 1885) }\end{array}$ & $3197-5060 \mathrm{~m}$ & $\begin{array}{l}\text { Indian Ocean; } \\
\text { NE Atlantic }\end{array}$ & Alcock 1901; Domansky 1986; Crosnier 1987 \\
\hline H. monnioti Crosnier, 1987 & $2663-4035 \mathrm{~m}$ & $\begin{array}{c}\text { Indian and } \\
\text { Atlantic Oceans }\end{array}$ & Cardoso 2013 \\
\hline $\begin{array}{l}\text { Hymenodora acanthi- } \\
\text { telsonis Wasmer, } 1972\end{array}$ & $5041-5591 \mathrm{~m}$ & $\begin{array}{l}\text { NW Pacific; } \\
\text { NE Atlantic }\end{array}$ & Kikuchi \& Omori 1985; Domansky 1986 \\
\hline H. frontalis Rathbun, 1902 & $586-4432 \mathrm{~m}$ & N Pacific & Rathbun 1902, 1910; Chace 1986; Marin 2018 \\
\hline $\begin{array}{c}\text { H. glacialis } \\
\text { Buchholz, } 1874\end{array}$ & $\begin{array}{l}\text { from near the } \\
\text { surface in } \\
\text { polar seas to } \\
5610 \mathrm{~m}\end{array}$ & $\begin{array}{l}\text { NE Atlantic, } \\
\text { Pacific and South } \\
\text { Oceans }\end{array}$ & $\begin{array}{l}\text { Havens \& Rork 1969; Butler 1980; Just 1980; } \\
\text { Wasmer 1986; Domansky 1986; Iwasaki \& Nemoto } \\
\text { 1987; Hendrickx \& Estrada Navarrete 1996; } \\
\text { Wicksten 2002; Basher \& Costello } 2014\end{array}$ \\
\hline H. gracilis (Smith, 1886) & $1000-3733 \mathrm{~m}$ & South Ocean & $\begin{array}{l}\text { Spence Bate 1888; Wasmer 1986; Iwasaki \& } \\
\text { Nemoto 1987; Gorny 1999; Basher \& Costello } 2014\end{array}$ \\
\hline $\begin{array}{l}\text { Meningodora mollis } \\
\quad \text { Smith, } 1882\end{array}$ & $840-2985 \mathrm{~m}$ & Atlantic and Pacific & $\begin{array}{c}\text { Chace 1940, 1986; Crosnier \& Forest 1973; } \\
\text { Kensley et al. } 1987\end{array}$ \\
\hline M. vesca (Smith, 1886) & $615-5367 \mathrm{~m}$ & Atlantic and Pacific & $\begin{array}{l}\text { Chace 1940, 1986; Crosnier \& Forest 1973; } \\
\text { Kensley et al. 1987; Allen \& Butler } 1994\end{array}$ \\
\hline $\begin{array}{l}\text { Notostomus elegans } \\
\text { A. Milne-Edwards, } 1881\end{array}$ & $0-3500 \mathrm{~m}$ & Atlantic and Pacific & $\begin{array}{c}\text { Crosnier \& Forest 1973; Chace 1986; } \\
\text { Kensley et al. } 1987\end{array}$ \\
\hline $\begin{array}{l}\quad N . \text { gibbosus } \\
\text { A. Milne-Edwards, } 1881\end{array}$ & $850-4000 \mathrm{~m}$ & Atlantic and Pacific & $\begin{array}{c}\text { Crosnier \& Forest 1973; Chace 1986; } \\
\text { Kensley et al. } 1987\end{array}$ \\
\hline \multicolumn{4}{|c|}{ Alvinocarididae Christoffersen, 1986} \\
\hline $\begin{array}{l}\text { Alvinocaris markensis } \\
\text { Williams, } 1988\end{array}$ & $1693-3650 \mathrm{~m}$ & $\begin{array}{l}\text { Atlantic, Mid- } \\
\text { Atlantic Ridge }\end{array}$ & $\begin{array}{l}\text { Williams 1988; Wharton et al. 1997; Shank et al. } \\
\text { 1999; Komai \& Segonzac 2003; Martin \& Haney } 2005\end{array}$ \\
\hline $\begin{array}{l}\text { A. methanophila } \\
\text { Komai et al., } 2005\end{array}$ & $2155-3712 \mathrm{~m}$ & NW Atlantic & Komai et al. 2005 \\
\hline $\begin{array}{c}\text { A. muricola } \\
\text { Williams, } 1988\end{array}$ & $1697-3277 \mathrm{~m}$ & $\begin{array}{l}\text { Atlantic, Gulf of } \\
\text { Mexico }\end{array}$ & $\begin{array}{l}\text { Williams 1988; Komai \& Segonzac 2005; } \\
\text { Komai et al. 2005; Martin \& Haney } 2005\end{array}$ \\
\hline
\end{tabular}


Table 1 (continued). Caridean shrimp species hitherto recorded from depths below $3000 \mathrm{~m}$.

\begin{tabular}{|c|c|c|c|}
\hline $\begin{array}{c}\text { Chorocaris chacei } \\
\text { Williams \& Rona, } 1986\end{array}$ & $1600-3650 \mathrm{~m}$ & $\begin{array}{l}\text { Atlantic, Mid- } \\
\text { Atlantic Ridge }\end{array}$ & $\begin{array}{l}\text { Williams \& Rona 1986; Williams 1987; } \\
\text { Martin \& Haney 2005; Komai \& Segonzac } 2008\end{array}$ \\
\hline $\begin{array}{l}\text { C. vandoverae Martin \& } \\
\text { Hessler, } 1990\end{array}$ & $3640 \mathrm{~m}$ & $\begin{array}{l}\text { Pacific, Mariana } \\
\text { Back Arc Basin }\end{array}$ & $\begin{array}{c}\text { Martin \& Hessler 1990; Martin \& Haney 2005; } \\
\text { Nye et al. } 2012\end{array}$ \\
\hline $\begin{array}{l}\text { Mirocaris fortunata } \\
\quad \text { (Martin \& } \\
\text { Christiansen, 1995) }\end{array}$ & $850-3480 \mathrm{~m}$ & $\begin{array}{l}\text { Atlantic, Mid- } \\
\text { Atlantic Ridge }\end{array}$ & $\begin{array}{l}\text { Martin \& Christiansen 1995; Vereshchaka 1997; } \\
\text { Shank et al. 1999; Komai \& Segonzac 2003; Martin \& } \\
\text { Haney 2005; Komai et al. 2007; Fabri et al. } 2011\end{array}$ \\
\hline $\begin{array}{c}\text { M. indica } \\
\text { Komai et al., } 2006\end{array}$ & $2422-3300 \mathrm{~m}$ & $\begin{array}{l}\text { Indian Ocean, } \\
\text { Central Indian } \\
\text { Ridge }\end{array}$ & Komai et al. 2006 \\
\hline $\begin{array}{l}\text { Opaepele susannae } \\
\text { Komai et al., } 2007\end{array}$ & $1500-2986 \mathrm{~m}$ & $\begin{array}{l}\text { Atlantic, Mid- } \\
\text { Atlantic Ridge }\end{array}$ & Komai et al. 2007; Beltenev et al. 2009 \\
\hline $\begin{array}{l}\text { Rimicaris exoculata } \\
\text { Williams \& Rona, } 1986\end{array}$ & $1700-4088 \mathrm{~m}$ & $\begin{array}{l}\text { Atlantic, Mid- } \\
\text { Atlantic Ridge }\end{array}$ & $\begin{array}{l}\text { Williams \& Rona 1986; Martin \& Haney 2005; Komai } \\
\text { et al. 2007; Komai \& Segonzac 2008; Nye et al. } 2012\end{array}$ \\
\hline $\begin{array}{l}\text { R. hybisae } \\
\text { Nye et al., } 2012\end{array}$ & $2300-4960 \mathrm{~m}$ & Atlantic, Caribbean & Nye et al. 2012 \\
\hline $\begin{array}{l}\text { R. kairei Watabe \& } \\
\text { Hashimoto, } 2002\end{array}$ & $2415-3320 \mathrm{~m}$ & $\begin{array}{l}\text { Indian Ocean, } \\
\text { Central Ind. Ridge }\end{array}$ & $\begin{array}{l}\text { Van Dover et al. 2001; Watabe \& Hashimoto 2002; } \\
\text { Martin \& Haney } 2005\end{array}$ \\
\hline \multicolumn{4}{|c|}{ Bythocarididae Christoffersen, 1987} \\
\hline $\begin{array}{c}\text { Bythocaris cryonesus } \\
\text { Bowman \& Manning, } 1972\end{array}$ & $3803-3805 \mathrm{~m}$ & $\begin{array}{l}\text { Arctic: Polar Sea; } \\
\text { Iceland }\end{array}$ & Bowman \& Manning 1972; Just 1980 \\
\hline $\begin{array}{l}\text { B. curvirostris } \\
\text { Kobjakova, } 1957\end{array}$ & $2352-3965 \mathrm{~m}$ & Arctic: Polar Sea & Just 1980 \\
\hline \multicolumn{4}{|c|}{ Crangonidae Haworth, 1825} \\
\hline $\begin{array}{l}\text { Neocrangon abyssorum } \\
\quad \text { (Rathbun, 1902) }\end{array}$ & $887-3200 \mathrm{~m}$ & N Pacific & $\begin{array}{l}\text { Birštein \& Vinogradov 1951; Zarenkov 1965; } \\
\text { Hiller-Adams \& Case 1985; Kim et al. } 2000\end{array}$ \\
\hline $\begin{array}{l}\text { Parapontophilus abyssi } \\
\quad \text { (Smith, 1884) }\end{array}$ & $1400-5852 \mathrm{~m}$ & Pacific and Atlantic & Crosnier \& Forest 1973; Chace 1984; Komai 2008 \\
\hline $\begin{array}{l}\text { P. occidentalis } \\
\text { (Faxon, 1893) }\end{array}$ & $837-4082 \mathrm{~m}$ & E Pacific & Faxon 1893; Komai 2008; Hendrickx \& Papiol 2015 \\
\hline $\begin{array}{c}\text { P. profundus } \\
(\text { Spence Bate, } 1888)^{*}\end{array}$ & $4755 \mathrm{~m}$ & Tasman Sea & Spence Bate 1888; Komai 2008 \\
\hline $\begin{array}{l}\text { P. talismani Crosnier \& } \\
\text { Forest, } 1973\end{array}$ & $3411-3517 \mathrm{~m}$ & $\begin{array}{l}\text { NE Atlantic; } \\
\text { Caribbean Sea }\end{array}$ & Crosnier \& Forest 1973; Gore 1985; Komai 2008 \\
\hline $\begin{array}{l}\text { Placopsicrangon formosa } \\
\text { Komai \& Chan, } 2009\end{array}$ & $4807-4824 \mathrm{~m}$ & W Pacific: Taiwan & Komai \& Chan 2009 \\
\hline $\begin{array}{c}\text { Sclerocrangon zenkevitchii } \\
\text { Birštein \& Vinogradov, } \\
1953\end{array}$ & $2995-3950 \mathrm{~m}$ & N Pacific & $\begin{array}{l}\text { Birštein \& Vinogradov 1953; } \\
\text { Kim et al. 2000; Komai } 2008\end{array}$ \\
\hline \multicolumn{4}{|c|}{ Disciadidae Rathbun, 1902} \\
\hline $\begin{array}{l}\text { Lucaya bigelowi } \\
\text { Chace, } 1939\end{array}$ & $4773 \mathrm{~m}$ & $\begin{array}{l}\text { Atlantic: } \\
\text { West Indies }\end{array}$ & Chace 1939 \\
\hline \multicolumn{4}{|c|}{ Eugonatonotidae Chace, 1937} \\
\hline $\begin{array}{c}\text { Eugonatonotus chacei } \\
\text { Chan \& Yu, } 1991 \\
\text { (as Galatheacaris abyssalis } \\
\text { Vereshchaka, 1997) }\end{array}$ & $2000-5000 \mathrm{~m}$ & $\begin{array}{l}\text { W Pacific: } \\
\text { Sulawesi }\end{array}$ & Vereshchaka 1997; Chow et al. 2000 \\
\hline
\end{tabular}

${ }^{*}$ Known from single holotype specimen.

${ }^{* *}$ G. abyssalis is a mesopelagic larva of E. chacei. The benthic species itself has not been recorded deeper than $1000 \mathrm{~m}$, but $G$. abyssalis can be collected in mid-water when trawls are hauled up from abyssal depths. Nevertheless, the records of G. abyssalis and E. chacei, respectively, are presented here as they were published in the literature. 
Table 1 (continued). Caridean shrimp species hitherto recorded from depths below $3000 \mathrm{~m}$.

\begin{tabular}{|c|c|c|c|}
\hline \multicolumn{3}{|c|}{ Glyphocrangonidae Smith, 1884} & \multirow[b]{2}{*}{ Holthuis 1971; Gore 1985} \\
\hline $\begin{array}{c}\text { Glyphocrangon atlantica } \\
\text { Chace, } 1939\end{array}$ & $3400-6373 \mathrm{~m}$ & Atlantic & \\
\hline $\begin{array}{l}\text { G. caecescens } \\
\text { Wood-Mason in Wood- } \\
\text { Mason \& Alcock, } 1891\end{array}$ & $2698-3431 \mathrm{~m}$ & Pacific and Indian & Komai 2004; Komai \& Komatsu 2016 \\
\hline $\begin{array}{l}\text { G. longirostris } \\
\text { (Smith, 1882) }\end{array}$ & $680-3219 \mathrm{~m}$ & & Hiller-Adams \& Case 1985 \\
\hline \multicolumn{4}{|c|}{ Nematocarcinidae Smith, 1884} \\
\hline $\begin{array}{l}\text { Nematocarcinus } \\
\text { acanthitelsonis } \\
\text { Pequegnat, } 1970\end{array}$ & $3138-3742 \mathrm{~m}$ & Atlantic & Crosnier \& Forest 1973; Gore 1985 \\
\hline N. batei Burukovsky, 2000 & & N Pacific & Burukovsky 2003 \\
\hline $\begin{array}{l}\text { N. challenger } \\
\text { Burukovsky, } 2006\end{array}$ & $5477 \mathrm{~m}$ & & Burukovsky 2006 \\
\hline N. ensifer (Smith, 1882) & $1000-3600 \mathrm{~m}$ & Atlantic & Crosnier \& Forest 1973; Gore 1985 \\
\hline $\begin{array}{c}\text { N. exilis } \\
\text { (Spence Bate, 1888) }\end{array}$ & $3300-4000 \mathrm{~m}$ & $\begin{array}{c}\text { Atlantic: } \\
\text { Mediterranean Sea }\end{array}$ & Company et al. 2004 \\
\hline $\begin{array}{c}\text { N. lanceopes } \\
\text { (Spence Bate, 1888) }\end{array}$ & $3432 \mathrm{~m}$ & South Ocean & $\begin{array}{c}\text { Spence Bate 1888; Hale 1941; Zarenkov 1968; Gutt et } \\
\text { al. 1991, 1994; Gorny 1992, 1999; Arntz et al. 1999; } \\
\text { Arntz 2003; Lovrich et al. 2005; } \\
\text { Basher \& Costello } 2014\end{array}$ \\
\hline $\begin{array}{l}\text { N. longirostris } \\
\text { (Spence Bate, 1888) }\end{array}$ & $2500-5340 \mathrm{~m}$ & $\begin{array}{l}\text { Atlantic, Pacific, } \\
\text { Indian and South } \\
\quad \text { Oceans }\end{array}$ & $\begin{array}{l}\text { Spence Bate 1888; Zarenkov 1968; Iwasaki \& } \\
\text { Nemoto 1987; Gorny 1999; Burukovsky 2003; } \\
\text { Yaldwyn \& Webber 2011; Komai \& Komatsu } 2016\end{array}$ \\
\hline $\begin{array}{c}\text { N. productus } \\
\text { Spence Bate, } 1888\end{array}$ & $631-3429 \mathrm{~m}$ & W Pacific & Chace 1986 \\
\hline \multicolumn{4}{|c|}{ Oplophoridae Dana, 1852} \\
\hline Oplophorus sp. & $944-5050 \mathrm{~m}$ & $\begin{array}{c}\text { Pacific: } \\
\text { off New Zealand }\end{array}$ & Lörz et al. 2012 \\
\hline $\begin{array}{l}\text { Systellaspsis braueri } \\
\quad \text { (Ba1ss, 1914) }\end{array}$ & $200-4000 \mathrm{~m}$ & $\begin{array}{l}\text { N Atlantic and } \\
\text { Pacific }\end{array}$ & $\begin{array}{c}\text { Chace 1940, 1986; Crosnier \& Forest 1973; } \\
\text { Martin \& Haney } 2005\end{array}$ \\
\hline S. cristata (Faxon, 1893) & $200-3200 \mathrm{~m}$ & $\begin{array}{l}\text { Indian, Pacific and } \\
\text { Atlantic Oceans }\end{array}$ & Holthuis 1951; Crosnier \& Forest 1968; Foxton 1970 \\
\hline $\begin{array}{c}\text { S. debilis } \\
\text { (A. Milne Edwards, 1881) }\end{array}$ & $150-5025 \mathrm{~m}$ & Indian Ocean & $\begin{array}{c}\text { Crosnier 1987; De Man 1920; Chace 1940, 1986; } \\
\text { Crosnier \& Forest 1973; Baba et al. 1986; } \\
\text { Kensley et al. } 1987\end{array}$ \\
\hline S. pellucida (Filhol, 1884) & $291-3292 \mathrm{~m}$ & Pacific and Atlantic & $\begin{array}{l}\text { Crosnier \& Forest 1973; Chace 1986; } \\
\text { Chan \& Yu 1986; Crosnier 1987; } \\
\text { Cardoso \& Young 2005; Komai et al. } 2018\end{array}$ \\
\hline \multicolumn{4}{|c|}{ Pandalidae Haworth, 1825} \\
\hline $\begin{array}{l}\text { Stylopandalus richardi } \\
\quad \text { (Coutière, 1905) }\end{array}$ & $0-3600 \mathrm{~m}$ & $\begin{array}{l}\text { Indian, Pacific and } \\
\text { Atlantic Oceans }\end{array}$ & $\begin{array}{l}\text { Chace 1940, 1986; Hayashi \& Miyake 1969; } \\
\text { Crosnier \& Forest 1973; Kensley et al. } 1987\end{array}$ \\
\hline \multicolumn{4}{|c|}{ Pasiphaeidae Dana, 1852} \\
\hline $\begin{array}{l}\text { Parapasiphae compta } \\
\text { Smith, } 1884\end{array}$ & $4990 \mathrm{~m}$ & Atlantic & Crosnier 1988 \\
\hline $\begin{array}{l}\text { Pasiphaea scotiae } \\
\text { (Stebbing, 1914) }\end{array}$ & $3660 \mathrm{~m}$ & South Ocean & $\begin{array}{l}\text { Wasmer 1986; Iwasaki \& Nemoto 1987; Tiefenbacher } \\
\text { 1991, 1994; Gorny 1999; Basher \& Costello } 2014\end{array}$ \\
\hline \multicolumn{4}{|c|}{ Sergestidae Dana, 1852} \\
\hline $\begin{array}{l}\text { Eusergestes arcticus } \\
\quad \text { (Krøyer, 1855) }\end{array}$ & $3935 \mathrm{~m}$ & South Ocean & $\begin{array}{c}\text { Doflein \& Balss 1912; Iwasaki \& Nemoto 1987; } \\
\text { Tiefenbacher 1994; Gorny } 1999\end{array}$ \\
\hline
\end{tabular}


MARIN I., Thoridae (Crustacea: Decapoda) can penetrate the Abyss

Table 1 (continued). Caridean shrimp species hitherto recorded from depths below $3000 \mathrm{~m}$.

\begin{tabular}{|c|c|c|c|}
\hline $\begin{array}{l}\text { Petalidium foliaceum } \\
\text { (Spence Bate, 1888) }\end{array}$ & $3935 \mathrm{~m}$ & South Ocean & $\begin{array}{l}\text { Spence Bate 1888; Hale 1941; Iwasaki \& } \\
\text { Nemoto 1987; Tiefenbacher 1991, 1994; Gorny } 1999\end{array}$ \\
\hline $\begin{array}{l}\text { Sergestes arachnipodus } \\
\text { (Cocco, 1832) }\end{array}$ & $3300-4000 \mathrm{~m}$ & $\begin{array}{c}\text { Atlantic: } \\
\text { Mediterranean Sea }\end{array}$ & Company et al. 2004 \\
\hline $\begin{array}{c}\text { Sergia robusta } \\
\text { (Smith, 1882) }\end{array}$ & $3300-4000 \mathrm{~m}$ & $\begin{array}{c}\text { Atlantic: } \\
\text { W Ionian Sea }\end{array}$ & Company et al. 2004 \\
\hline \multicolumn{4}{|c|}{ Stylodactylidae Spence Bate, 1888} \\
\hline Bathylodactylus sp. & $3922 \mathrm{~m}$ & $\begin{array}{l}\text { Pacific: Clarion- } \\
\text { Clipperton Zone }\end{array}$ & Amon et al. 2017 \\
\hline $\begin{array}{c}\text { Bathystylodactylus } \\
\text { bathyalis (Cleva, 1994) }\end{array}$ & $3502-3515 \mathrm{~m}$ & $\begin{array}{l}\text { W Pacific: } \\
\text { Coral Sea }\end{array}$ & Cleva 1994 \\
\hline $\begin{array}{l}\text { B. cf. bathyalis } \\
\text { (Cleva, 1994) }\end{array}$ & $4826 \mathrm{~m}$ & $\begin{array}{l}\text { Pacific: Marianas } \\
\text { Trench Marine Natl } \\
\text { Monument }\end{array}$ & Wicksten et al. 2017 \\
\hline $\begin{array}{l}\text { B. inflatus Hanamura \& } \\
\text { Takeda, } 1996\end{array}$ & $3436-3452 \mathrm{~m}$ & W Pacific: Taiwan & Hanamura \& Takeda 1996 \\
\hline \multicolumn{4}{|c|}{ Thoridae Kingsley, 1879} \\
\hline Lebbeus sokhobio sp. nov. & $3301-3366 \mathrm{~m}$ & $\begin{array}{l}\text { NW Pacific: } \\
\text { Sea of Okhotsk }\end{array}$ & Marin 2018; present study \\
\hline
\end{tabular}

1.5 nautical miles (depending on the depth) at a vessel speed of 1 knot, and trawling lasted for 10-20 minutes at a speed of 1.0 knot. As soon as the AGT arrived on deck, all animals were removed from the catch during sieving of the sediment. Large organisms removed from the AGT were stored in cooled seawater until further treatment, then preserved in a $96 \%$ solution of ethanol and stored at $0{ }^{\circ} \mathrm{C}$. Some specimens were photographed in parallel with the preservation process.

Drawings of preserved specimens were made with the help of a camera lucida attached to an Olympus binocular microscope. Postorbital carapace length (pcl., in $\mathrm{mm}$ ), i.e., the length from the orbits to the posterodorsal margin of the carapace, and total body length (tl., in $\mathrm{mm}$ ), i.e., the dorsal length from the tip of the rostrum to the distal margin of the telson, are used as standard measurements. The material is deposited in the Zoological Museum of Moscow State University, Moscow (ZMMU, holotype), the Zoological Museum of the National Scientific Center of Marine Biology FEB RAS, Vladivostok (MIMB) and Naturmuseum Senckenberg, Frankfurt am Main, Germany (SMF).

To study molecular genetic barcodes, fragments of the mitochondrial gene coding cytochrome c oxidase subunit I (COI mtDNA), mitochondrial 16S ribosomal RNA (16S rRNA) and nuclear 28S ribosomal RNA (28S rRNA) gene markers were amplified and sequenced. Total genomic DNA was extracted from muscle tissue using the innuPREP DNA Micro Kit (AnalitikJena, Germany) following the manufacturer's protocol. The COI mtDNA gene marker was amplified with the help of the universal primers LCO1490 (5'-ggtcaacaaatcataaagatattgg-3'), HC02198 (5'-taaacttcagggtgaccaaaaaatca-3') (Folmer et al. 1994), for 16S rRNA (16SAR-cgcctgtttatcaaaaacat, 16SBR-ccggtctgaactcagatcacgt) after Palumbi et al. (2002), for 28S rRNA (28SA-gacccgtcttgaaacacgga, 28SB-tcggaaggaaccagctacta) primers after Whiting et al. (1997). PCR was performed with the T100 amplificator (Bio-Rad, USA) under the following conditions: initial denaturation at $96^{\circ} \mathrm{C}$ for 1.5 minutes followed by 42 cycles of $95^{\circ} \mathrm{C}$ for 2 minutes, $49^{\circ} \mathrm{C}$ for 35 seconds, and $72^{\circ} \mathrm{C}$ for 1.5 minutes, followed by chain extension at $72^{\circ} \mathrm{C}$ for 7 minutes. A volume of $10 \mu 1$ of the reaction mixture contained $1 \mu 1$ of total DNA, $2 \mu 1$ of $5 \times \mathrm{PCR}$ mix (Dialat, Russia) and $1 \mu 1$ of each primer. The amplification products were separated by using gel electrophoresis of nucleic acids on a 1.5\% agarose gel in $1 \times \mathrm{TBE}$, and then stained and visualized with $0.003 \% \mathrm{EtBr}$ using imaging UV software. DNA nucleotide sequences were determined using Genetic 
Analyzer ABI 3500 (Applied Biosystems Inc.) and BigDye ver. 3.1 (Applied Biosystems Inc.) with direct and reverse primers.

The aligned sequences of the COI mtDNA gene markers, 635 base pairs in length, were analyzed for pairwise sequence divergence ( $p$-distances) and used to construct the phylogenetic relationships, whereas data on $16 \mathrm{~S}$ and $28 \mathrm{~S}$ are only presented in the 'GenBank accession numbers' section, as there are no sequences to compare them to in GenBank (NCBI) or any other genetic database. The dataset of COI mtDNA gene marker alignments used in this study is presented in Appendix 1. The best evolutionary substitution model was determined using MEGA ver. 7.0. and jModeltest ver. 2.1.141 via the CIPRES Science Gateway ver. 3.3 (http://www.phylo.org/). Phylogenetic analysis was performed using MrBayes ver. 32.6 for the Bayesian analysis $(\mathrm{BA})$ with an $\mathrm{NKY}+\mathrm{I}+\mathrm{G}$ evolutionary model and using $\mathrm{RA} \times \mathrm{ML}$ ver. 8.0.0 with a GTR $+\mathrm{I}+\mathrm{G}$ evolutionary model for the Maximum-Likelihood analysis (ML). Bayesian analysis was carried out by sampling one tree every 1000 generations over 1000000 generations. Values of confidence (bootstrap support) $>50 \%$ are presented for BA/ML analyses; the divergences of $p$-distances are calculated using the Kimura-2-parameter (K2P) model in MEGA. The phylogenetic tree obtained based on COI mtDNA is presented in Fig. 7; there are no data on other species of Lebbeus based on the other gene markers (16S rRNA and 28S r RNA) for any valuable analysis, so they are just presented in this paper for future research.

Existing records of caridean shrimps below depths of $3000 \mathrm{~m}$ are presented in Table 1. It is based on the available literature found on the Internet using keywords as well as on a special search for scientific information in libraries using reference journals and electronic catalogs to search in publications not found on the Internet. It is possible that some pelagic species (e.g., members of Oplophoridae, Pasiphaeidae and Sergestidae) can be caught by trawls when they were hauled up from abyssal depths. The table includes all published records of caridean shrimps when the sampling depth was indicated as being deeper than $3000 \mathrm{~m}$, without any assessment. Moreover, pelagic shrimps are often eurybathic and recorded by video vehicles from abyssal depths (e.g., Lörz et al. 2012; Jamieson et al. 2009; Wicksten et al. 2017; pers. obs.). Some remarks, for example for Galatheacaris abyssalis Vereshchaka, 1997, are presented in the text (see Table 1).

\section{Results}

Class Malacostraca Latreille, 1802

Order Decapoda Latreille, 1802

Family Thoridae Kingsley, 1879

Genus Lebbeus White, 1847

Lebbeus sokhobio sp. nov. urn:1sid:zoobank.org:pub:7F2F71AA-4282-477C-9D6A-4C5FB417259D

Figs $1-6$

Lebbeus sp. - Marin 2018: 331.

\section{Type material}

\section{Holotype}

SEA OF OKHOTSK - + ; NE slope of Kuril Basin, st. 1-10; $46^{\circ} 08.9^{\prime} \mathrm{N}, 145^{\circ} 59.4^{\prime}$ E- $46^{\circ} 09.0^{\prime} \mathrm{N}$, $145^{\circ} 59.5^{\prime}$ E; depth 3303-3308 m; 10 Jul. 2015; ZMMU Ma5836.

\section{Paratypes}

SEA OF OKHOTSK • 1 ; ; same collection data as for holotype; ZMMU Ma6096 • 1 ; ; NE slope of Kuril Basin, st. 4-3; 47 14.0' N, 149 34.8' E; AGT; depth 3366 m; 16 Jul. 2015; ZMMU Ma6097 •

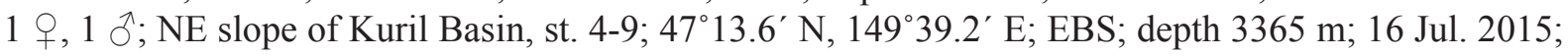


SMF $51579 \cdot 2$ ôे, 1 juv.; NE slope of Kuril Basin, st. 4-10; $47^{\circ} 12.2^{\prime} \mathrm{N}, 149^{\circ} 36.7^{\prime}$ E; EBS; depth 3366 m; 17 Jul. 2015; MIMB 39426 • 1 क; NE slope of Kuril Basin, st. 7-12; 46⒌ $54.6^{\prime}$ N, $151^{\circ} 03.7^{\prime}$ E; AGT; depth 3301 m; 22 Jul. 2015; MIMB 39427.

\section{Etymology}

This new species is named after the SokhoBio (Sea of Okhotsk Biodiversity Study) Expedition 2015, which allowed the collection of numerous deep-sea species such as this one.

\section{Description}

CARAPACE (Figs 2, 3A-B). Smooth, without setae; dorsal surface slightly convex in males and gibbous in females, with well-marked postrostral median ridge armed with 2 postrostral teeth located at about anterior 0.2 of carapace length (Fig. 5); antennal tooth situated slightly below suborbital angle (Figs 3A-B, 5); supraorbital tooth large, directed forward, with deep notch below base, situated anterior rostral base; suborbital lobe prominent, triangular; anterolateral margin between antennal and pterygostomial teeth strongly sinuous, with deep concavity below antennal tooth; pterygostomial tooth acute, smaller and more slender than antennal and supraorbital teeth, overreaching anterior margin of carapace (Fig. 3A-B).

ORBITS. Well developed, orbital margin with slight convexity posteriorly, base of eyestalk located between this convexity and suborbital lobe.

RostRum. Relatively long, compressed, reaching distal margin of basal segment of antennular peduncle (Fig. 3A-B), about 0.3 times as long as carapace; rostral formula 1-2+2/1-3 (Fig. 5), with welldeveloped dorsal and ventral lamina; lateral rostral carina obsolescent, situated above level of proximal orbital margin (Fig. 2A).

Pleon (Figs. 2, 3C). Smooth and unarmed dorsally; pleomere II with distinct anterior transverse groove on tergum; pleurae of pleomeres I-IV rounded, pleurae of pleomere IV pointed posteroventrally in some specimens (Fig. 3C); pleurae of pleomere V (Fig. 3C) with small posteroventral tooth; pleomere VI (Fig. 3G) with small posteroventral teeth and posterolateral process terminating acutely. Telson (Fig. 3G) slender, about 4 times as long as proximal width, narrowing posteriorly, with 3-5 (usually 4) pairs of small submarginal dorsal spines at $0.4,0.75,0.8$ and 0.9 of telson length; posterior margin armed with 3 or 4 pairs (usually 4 , but 3 pairs in possibly damaged specimens) of unequal spines or spiniform setae (Fig. 3H).

EyEs (Fig. 3A-B). Normal, well developed, subpyriform, with subcylindrical eyestalk and large dilated cornea; eyestalk about as long as wide; cornea subglobose, without papilla; ocellus absent.

AnTENNUla. Antennular peduncle (Fig. 3A, D-E) well developed; basal segment about twice as long as wide, with dorsodistal margin armed with 3 slender spines; stylocerite well developed, acute, nearly reaching distal margin of basal segment, mesial margin sinuous; intermediate segment (article 2) stout, about 1.5-2.0 times as long as wide, with slightly convex mesial margin bearing long plumose setae and slender distolateral tooth; distal segment (article 3) short, about as long as wide, about half the length of intermediate segment, with acute dorsolateral subdistal tooth, with long plumose setae along mesial margin; upper antennular flagellum with aesthetasc-bearing portion consisting of 10-12 articles. No sexual dimorphism detected.

AnTEnNa (Fig. 3F). Normal, well developed; basicerite armed with small tooth ventrolaterally; carpocerite overreaching midlength of scaphocerite; flagellum well developed; scaphocerite wide, greatly overreaching antennular peduncle, about 3 times as long as maximal width, with well-developed distolateral tooth reaching distal margin of blade. 
MouthPARTS. Typical for genus, without distinctive features. Mandible with 2-segmented palp; incisor process well-marked, terminating in sharp tip, bearing 4 distinct teeth and several additional denticles; molar process terminating distally. Maxilla I consisting of well-developed and partly fused endites, armed with spiniform setae and unsegmented bilobed palp. Maxilla II with simple, slender blunt palp; upper endite bilobed, fringed with setae; lower endite reduced; scaphognathite well developed, with rounded posterior lobe. Maxilliped I with partly fused endites, bearing short stout setae along distal margin as well as some elongated setose setae along distodorsal angle; exopod well developed, with

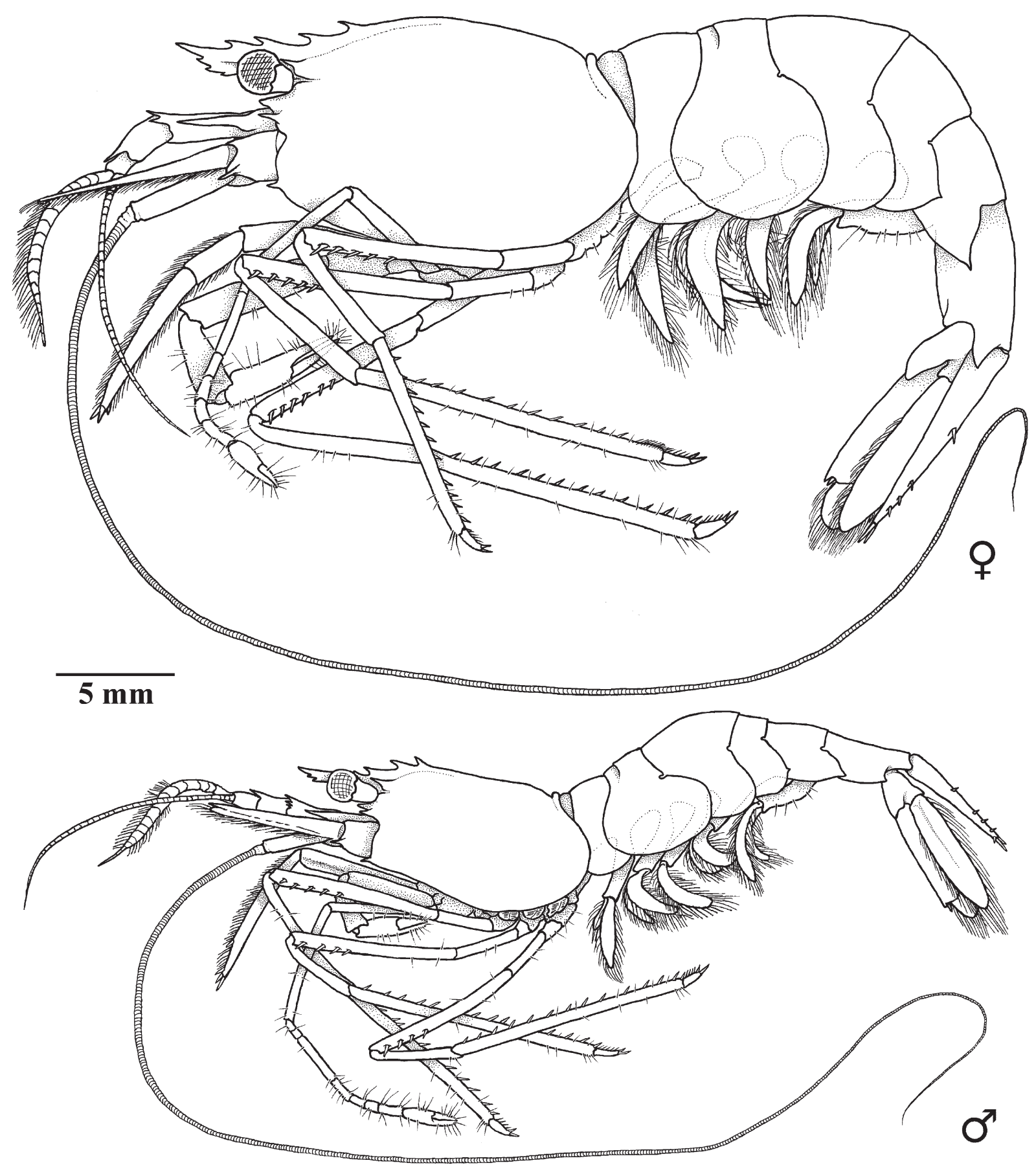

Fig. 2. Lebbeus sokhobio sp. nov., general view, $q$ from st. 4-3 (paratype, ZMMU Ma6097) and $\delta$ from st. 4-9 (paratype, SMF 51579). 


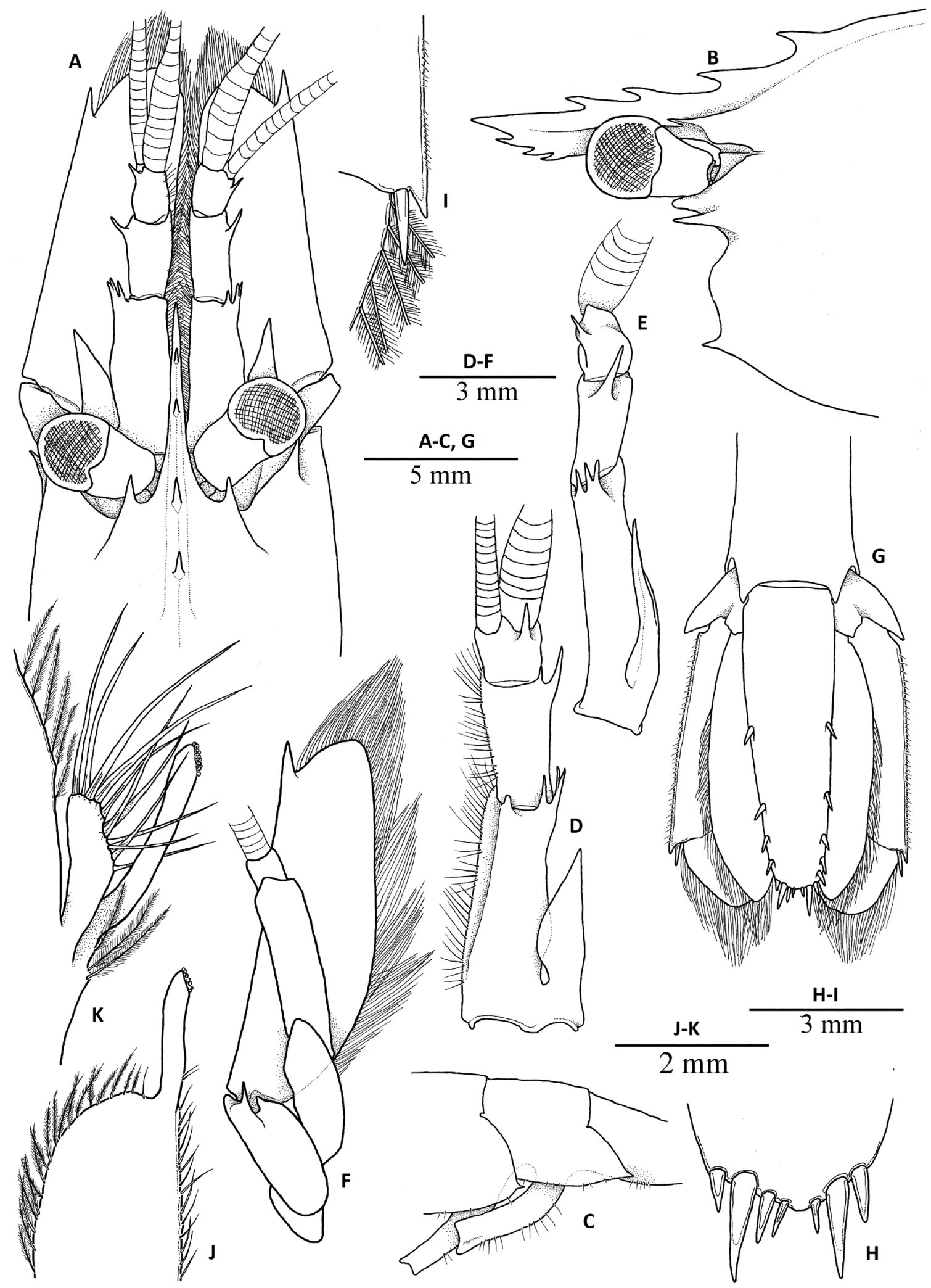

Fig. 3. Lebbeus sokhobio sp. nov.,,+ from st. 4-3 (paratype, ZMMU Ma6097) (A-I) and $\widehat{\partial}$ from st. 4-10 (paratype, MIMB 39426) (J-K). A-B. Anterior part of carapace. C. Abdominal pleonites IV-V, lateral view. D-E. Antennula. F. Antenna. G. Telson and uropods. H. Distal margin of telson. I. Distolateral margin of exopod. J. Endopod of pleopod I. K. Endopod of pleopod II. 


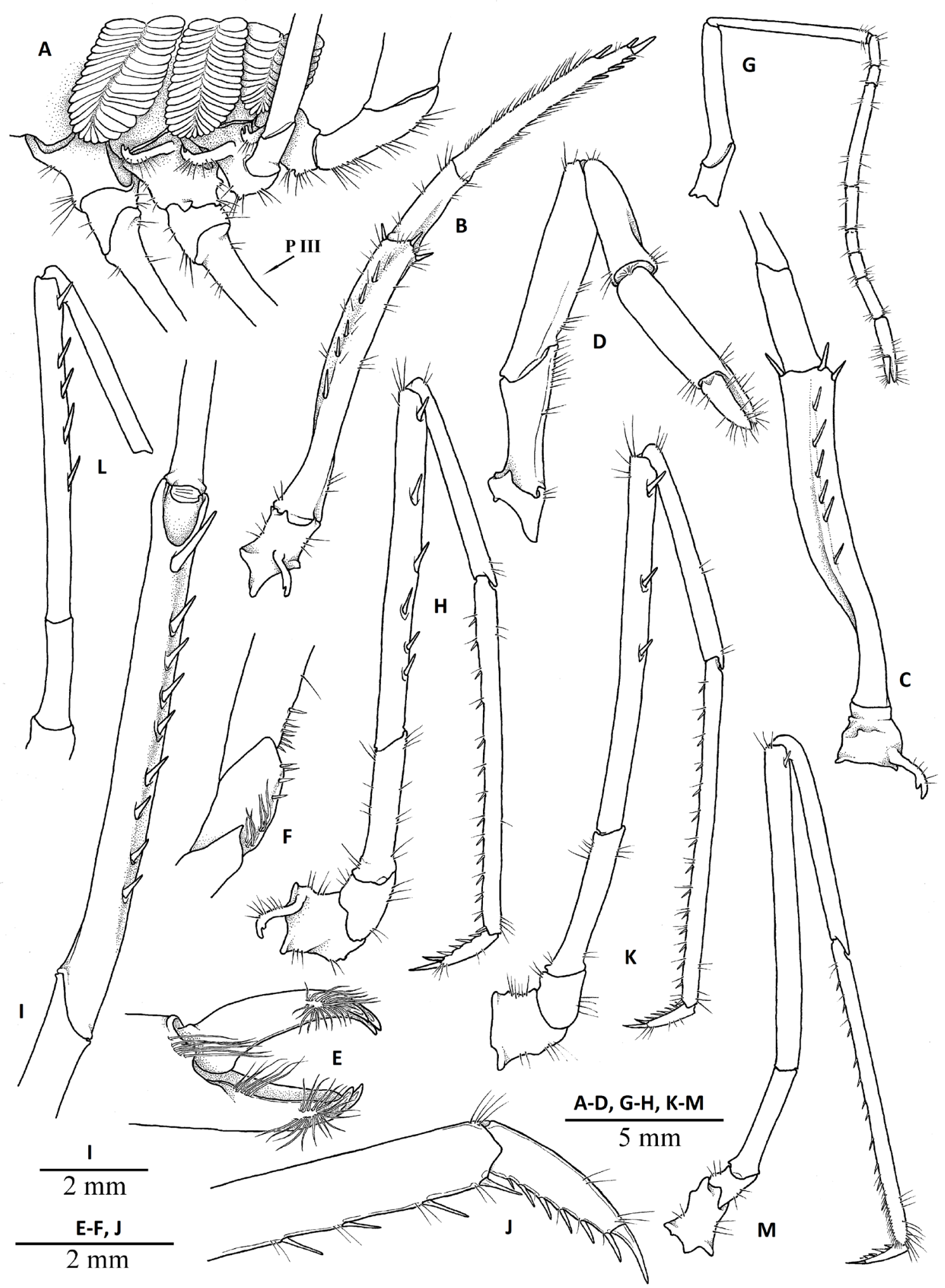

Fig. 4. Lebbeus sokhobio sp. nov., q from st. 4-3 (paratype, ZMMU Ma6097) (A-H, J-K, M) and § from st. 4-9 (paratype, SMF 51579) (I, L). A. Basal segments of pereiopods I-III. B. Maxilliped III. C. Antepenultimate segment of maxilliped III. D. Pereiopod I. E. Chela of pereiopod I. F. Proximal segments of pereiopod I. G. Pereiopod II. H. Pereiopod III. I. Merus of pereiopod III. J. Dactylus of pereiopod III. K. Pereiopod IV. L. Merus of pereiopod IV. M. Pereiopod V. 
well-marked caridean lobe with many setae; palp 2-segmented; epipod ear-shaped, bilobed distally. Maxilliped II with well-developed exopod, fringed with setae distally; ischium stout, with long setae along lateral margin; propodus short, length equal to that of dactylus, with convex dorsal margin furnished with long simple setae, ventral margin unarmed; dactylus convex, armed with numerous stout, long, simple setae along distal margin; exopod flagellate; epipod well-marked, distally bilobed, with podobranch. Maxilliped III (Fig. 4B-C) moderately long and stout, slightly overreaching scaphocerite and antennular peduncle; epipod well developed; exopod absent; antepenultimate article about 6 times as long as wide, slightly tapering distally, with longitudinal row of long spiniform setae along lateral surface and 3 long spiniform setae on distal margin; penultimate article about twice as long as wide, smooth; terminal segment about 7 times as long as wide, with distal margin oblique, armed with row of spines along distomesial margin.

Pereiopod I (Fig. 4D). Moderately robust; coxa with epipod and setobranch; basis stout, unarmed; ischium stout, about twice as long as wide, with long, simple setae along ventral margin; merus slender, about 4 times as long as wide, with row of spiniform setae proximally (Fig. 4F); carpus robust, about half the length of merus and slightly shorter than propodus, about twice as long as wide, slightly flaring distally; distal margin slightly overlapping carpo-propodal articulation; mesial surface with grooming apparatus consisting of shallow concavity and complex of short, stiff setae; propodus (palm) about 3 times as long as wide, subcylindrical, smooth; fingers (Fig. 4E) stout, about half the length of palm, subspatulate, about as long as wide; cutting edges straight, with strong distal teeth.

PeReIOPOD II (Fig. 4G). Relatively slender, unarmed; coxa with setobranch and epipod; basis small, about as long as wide; ischium about 4 times as long as wide, smooth; merus about 7 times as long as wide; carpus subdivided into 7 sub-articles with ratio of about 1:1:4:2:1:1:2; propodus (palm) subcylindrical, slightly shorter than distal carpal segment, about twice as long as wide and twice as long as fingers, with straight smooth margins; fingers slender, about 1.5 times as long as wide, with straight cutting edges.

Pereiopods III-V. Similar, relatively slender. Pereiopod III (Fig. 4H) coxa with setobranch and terminally hooked epipod; basis with small lobe distoventrally, about as long as wide; ischium about 3.5-4.0 times as long as wide; merus about 9 times as long as wide, armed with 5-8 movable spines on lateral surface adjacent to ventral margin on distal $4 / 5$; carpus about 6 times as long as maximal width, slightly widened distally; propodus about 10-11 times as long as wide, with straight margins, ventral margin armed with tooth-like setae; dactylus (Fig. 4J) slender, terminating in elongate curved unguis, with 6-7 small accessory spinules, increasing in length distally. Pereiopods IV (Fig. 4K) and V (Fig. 4M) without epipod; merus of pereiopod V (Fig. 4L) with a single spine subterminally; propodus of pereiopod V with brush-like cluster of setae (Fig. 4M) (grooming apparatus) on flexor margin distally.

PLEopods. Endopod of pleopod I with terminally located appendix interna and row of curved spinulelike setae along mesial margin in males (Fig. 3K). Pleopod II in males with appendix masculina shorter than appendix interna (Fig. 3J), truncate terminally, bearing 10-12 long simple setae on distal and mesial surfaces. Uropods moderately slender, exceeding telson (Fig. 3G); distolateral margin of exopod with fixed posterolateral tooth and slender mobile spine (spiniform seta).

Coloration. Body and appendages entirely vermilion, antennular and antennal flagella white; corneas of eyes with golden reflection (Fig. 6).

Size. Largest female (holotype) has pcl. $19.0 \mathrm{~mm}$ and tl. $62 \mathrm{~mm}$. Largest male has pcl. $17.0 \mathrm{~mm}$ and tl. $56 \mathrm{~mm}$. 


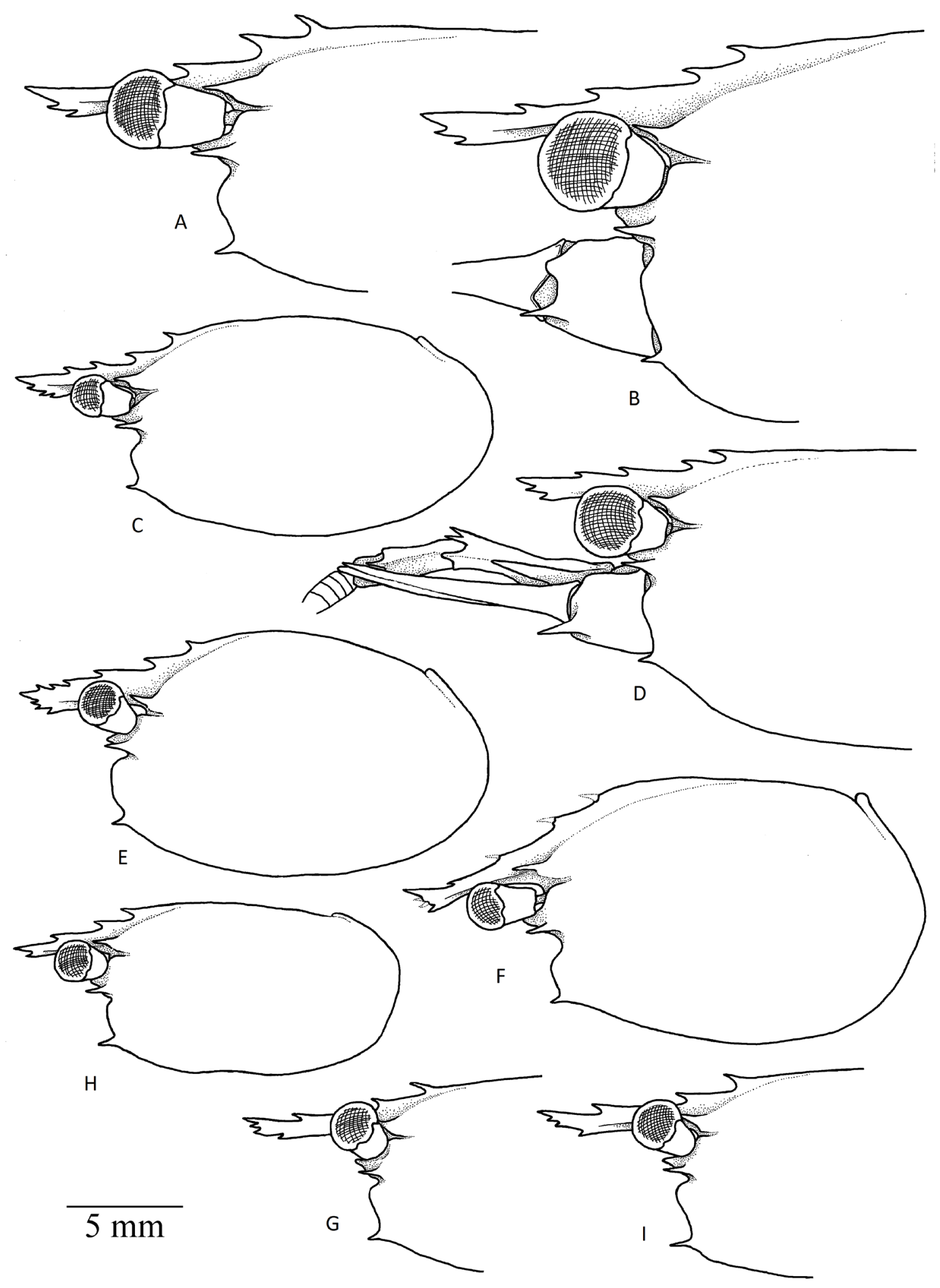

Fig. 5. Lebbeus sokhobio sp. nov., carapaces. A. $\widehat{\jmath}$ from st. 4-9 (paratype, SMF 51579). B. $ᄋ$ from st. 1-10 (holotype, ZMMU Ma5836). C. + from st. 7-12 (paratype, MIMB 39427). D. o from st. 4-9 (paratype, SMF 51579). E. § from st. 1-10 (paratype, ZMMU Ma6096). F. o from st. 4-3 (paratype, ZMMU Ma6097). G. $\bigcirc$ from st. 4-10 (paratype, MIMB 39426). H. Juvenile from st. 4-10 (paratype, MIMB 39426). I. $\sigma^{\Uparrow}$ from st. 4-10 (paratype, MIMB 39426). 


\section{Remarks}

The new species described here belongs to the species group of the genus Lebbeus characterized by the presence of strap-like epipods on maxilliped III and pereiopod III. This species group includes L. africanus Fransen, 1997, L. antarcticus (Hale, 1941), L. bidentatus Zarenkov, 1976, L. brevirostris Chang et al., 2010 (described based on a possibly juvenile specimen), L. carinatus Zarenkov, 1976, L. cristatus Ahyong, 2010, L. formosus Chang et al., 2010, L. indicus Holthuis, 1947 (questionable), L. java Komai et al., 2019, L. kuboi Hayashi, 1992, L. lamina Komai, 2013, L. laurentae Wicksten, 2010, L. microceros (Krøyer, 1841), L. pacmanus Komai et al., 2012, L. polyacanthus Komai et al., 2004, L. profundus (Rathbun, 1906), L. saldanhae (Barnard, 1947), L. shinkaiae Komai et al., 2012, L. similior Komai \& Komatsu, 2009, L. thermophilus Komai et al., 2012, L. tosaensis Hanamura \& Abe, 2003, L. unguiculatus Chang et al., 2010, L. vicinus (Rathbun, 1902), L. virentova Nye et al., 2013, L. washingtonianus (Rathbun, 1902) and L. wera Ahyong, 2009. The wide geographical distribution and isolation of some deep regions (e.g., Antarctica vs the Sea of Okhotsk, etc.) suggests the hypothesis that numerous endemic deep water species are present within this group (e.g., Hayashi 1992; Komai et al. 2004, 2012, 2019; Komai 2013, 2015; Anosov et al. 2018). Lebbeus sokhobio sp. nov. is the only species of this group found in the northern part of the NW Pacific, the Sea of Okhotsk. The geographically closest species is L. lamina described from deep waters off the Izu Islands, Japan.

At the same time, the phylogenetic significance of grouping based on marked morphological features is rather doubtful (Komai et al. 2019) and has not yet been proven due to the lack of sufficient genetic data (see below). However, based on the presence of epipods on the basis of pereiopods I-III, the shape and armament of telson, with 4 pairs of dorsal spines, and the relatively slender dactyli of the ambulatory pereiopods, armed with numerous small accessory spinules, the new species may be close to

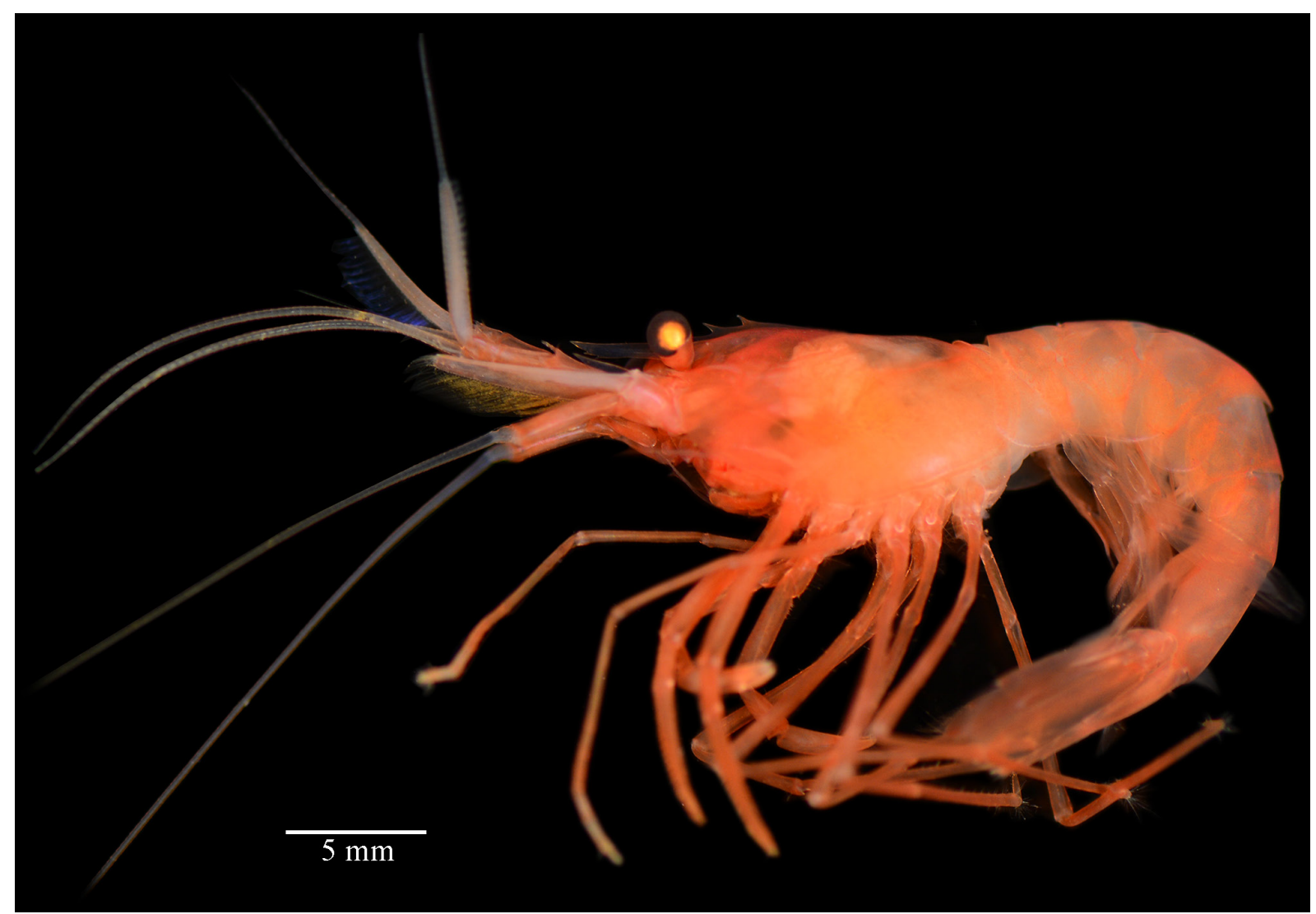

Fig. 6. Lebbeus sokhobio sp. nov., ô from st. 4-9 (paratype, SMF 51579), live coloration. 
L. africanus from Mauritania, at a depth of $1500 \mathrm{~m}$ (Fransen 1997), L. antarcticus from the South Ocean, at depths of 450-1775 m (Nye et al. 2013b), L. bidentatus known from off Chile, at a depth of $1680 \mathrm{~m}$ (Zarenkov 1976; Fransen 1997), L. carinatus collected off Peru, at depths of 1680-1860 m (Zarenkov 1976; Fransen 1997), L. cristatus from New Zealand, at depths of 1231-1226 m (Ahyong 2010), L. formosus from Taiwan, at depths of 635-1982 m (Chang et al. 2010), L. java from south of Java, at depths of 637-689 m (Komai et al. 2019), L. saldanhae collected along the coasts of South Africa (Saldanha Bay), at a depth of about $265 \mathrm{~m}$ (145 fms) (Fransen 1997), L. similior from Japan, at a depth of $1196 \mathrm{~m}$ (Komai \& Komatsu 2009), L. unguiculatus from Taiwan and Japan, at depths of 742-1262 m (Chang et al. 2010; Komai 2011), L. vicinus known from along the Pacific coasts of North America from Alaska to Mexico, at depths of 954-2824 m (Rathbun 1902, 1904; Wicksten \& Mendez 1982) and L. virentova from the Mid-Cayman Spreading Center, Caribbean Sea, at a depth of 2294-2375 m (Nye et al. 2013a). The morphological features shared among these species include: short styliform rostrum, not reaching distal margin of second antennular segment, armed with 4 or more dorsal teeth, including postrostral teeth and with more than 1 ventral tooth; distinct U- or V-shaped notch inferior to base of supraorbital tooth; sinuous anterolateral margin of carapace between antennal and pterygostomial teeth with deep excavation below antennal tooth; pleomere II with distinct anterior transverse groove on tergum; basal antennular segment with 2 or 3 dorsodistal teeth; dactyli of ambulatory pereiopods armed with accessory spiniform spinules over entire length of flexor margin (after Nye et al. 2012, with some modifications).

Some morphological features allow the separation of $L$. sokhobio sp. nov. from some of the other species in this group mentioned above. The new species is distinguishable from $L$. java by the different rostral formula and the presence of $4(2+2)$ dorsal rostral teeth $(v s 3(2+1)$ in $L$. java); the presence of 4 or 5 pairs of dorsal spines on the telson (vs 3 in $L$. java); inner distal spines on the telson much shorter than those in L. java (Komai et al. 2019: fig. 2e); shorter stylocerite of the basal antennular segment not reaching the distal margin of the segment (vs reaching the distal margin in L. java; Komai et al. 2019: fig. 2b); distal part of penultimate article of maxilliped III (Fig. 4A) with fewer but more slender spines than in L. java (Komai et al. 2019: figs 2g, 3a); merus of pereiopod III armed with 6-9 movable teeth at the distal angle (vs a maximum of 5 in $L$. java); and the different number of lateral spines on the meri of pereiopods III-V (see Fig. 4F-G, I-K vs Komai et al. 2019: figs 3e-f).

Lebbeus virentova can be separated from the new species by its shorter rostrum, with 3 postrostral teeth (Nye et al. 2013a: fig. 2a-b) (vs rostrum significantly overreaching cornea, with only 2 postrostral teeth in L. sokhobio sp. nov.; Figs 3B, 5), the presence of 3 well marked dorsal rostral teeth (Nye et al. 2012: fig. 2b) (vs only 2 teeth in the new species; Figs 3B, 5), and its white coloration (Nye et al. 2013a: fig. 5) (vs vermillion coloration in the new species; Fig. 6). Moreover, L. virentova is known only from the Caribbean Sea.

Another very geographically distant species, L. laurentae, although rather poorly described, can be separated from L. sokhobio sp. nov. by the more slender distal part of the rostrum and its feebly marked dorsal and ventral armature (Wicksten 2010; Komai et al. 2012) in contrast to the rostrum of the new species, which has well-marked dorsal teeth and some extension in the distal part, with well-developed ventral teeth (Figs 3B, 5).

Lebbeus sokhobio sp. nov. can be separated from L. antarcticus by the more slender distal part of the rostrum (Nye et al. 2013b: fig. 8b) (vs rostrum with some extension in the distal part, with well-developed ventral teeth in the new species; Figs 3B, 5) and the presence of 3 postrostral teeth (see Nye et al. 2013b: fig. 8b) (vs 2 in the new species).

Lebbeus cristatus and L. formosus differ from the new species in having a more slender and short rostrum (Ahyong 2010: fig. 1a-c; Chang et al. 2010: fig. 4a-b), a different armature of the distal margin 
of the basal antennular segment (Ahyong 2010: fig. 1d; Chang et al. 2010: fig. 4a-b) and of the posterior margin of the telson (Ahyong 2010: fig. 1g; Chang et al. 2010: fig. 4e), and a smaller number of lateral spines on the meri of pereiopods III-V (Ahyong 2010: fig. 1d-g; Chang et al. 2010: fig. 5e, g-h).

Lebbeus lamina and L. unguiculatus can also be clearly separated from the new species. Lebbeus lamina can be separated by its shorter rostrum and 3 postrostral dorsal teeth (vs only 2 in the new species), 7 pairs of small dorsal sublateral spines (vs only 4 pairs of relatively long spines in the new species), a different armature of the posterior margin of the telson (5-6 pairs of distal spines in L. lamina vs 4 in the new species), a smaller number of meral spines (4 in L. lamina vs 5-9 in L. sokhobio sp. nov.) and stouter dactyli of pereiopods III-V (after Komai 2013). Lebbeus unguiculatus differs in having a shorter rostrum and longer stylocerite, rounded pleura of pleonite IV (vs pointed in the new species), a different armature of the posterior margin of the telson (5 pairs of distal spines in L. unguiculatus vs 4 in the new species) and fewer lateral spines on the meri of pereiopods III-V (after Chang et al. 2010).

\section{Genbank accession numbers}

COI: MN590012 (holotype), MN590013-MN590015, MN608153-MN608155.

\section{Genetic differences}

The intraspecific pairwise genetic distances ( $p$-distances) within the studied population of Lebbeus sokhobio sp. nov. $(\mathrm{n}=7)$ is $0.004 \pm 0.002(\mathrm{~d} \pm \mathrm{ES})$, which is rather low. Also, the genetic differences between specimens from different stations and the intraspecific differences among specimens from one station are very similar. Genetic $p$-distances between known species of the genus vary from 0.014 to 0.16 substitutions per 100 nucleotide positions (see Table 2), showing that the interspecific genetic differences of closely related species from different, sometimes very distant, regions of the World Ocean (e.g., L. antarcticus, L. virentova and L. sokhobio sp. nov.; see Fig. 7) are only slightly different from the intraspecific differences within the Kuril Basin of the Sea of Okhotsk. Unfortunately, much genetic data from genetic markers other than COI mtDNA are not currently available. However, it is very interesting that the genetically closest (= phylogenetically related) species among representatives of the genus Lebbeus are distributed most distantly $-L$. antarcticus from the Southern Ocean and L. virentova from the Caribbean (see Fig. 7). The genetic $p$-distances (Table 2) between these species are lower than previously documented for caridean shrimps (Knowlton et al. 1993; Knowlton \& Weigt 1998; Hebert et al. 2003; Sites \& Marshall 2004; Zakšek et al. 2007; Lefébure et al. 2006a, 2006b; Marin 2017).

At the same time, available barcoding data show that all of the deepest dwelling species belong to the same phylogenetic clade (see Fig. 7; 'Deep-sea Lebbeus' clade) showing a low level of divergence among species, whereas their species are very widely distributed. Similar small interspecific distances of about $1-2 \%$ are also known from very distantly living species of other deep-sea caridean shrimps (e.g., Mirocaris Vereshchaka, 1997 (Alvinocarididae); Shank et al. 1999; Vereshchaka et al. 2015; data from GenBank), as well as other deep-sea invertebrate taxa such as bivalve mollusks (e.g., Abyssogena Krylova et al., 2010 (Vesicomyidae); Liu \& Zhang 2018) and octocorals (France \& Hoover 2002). Low interspecific genetic differences in COI mtDNA were observed exclusively in deep-sea taxa, but, for example, not in all studied deep-sea caridean shrimps (e.g., Shank et al. 1999; Vereshchaka et al. 2015; Zhang et al. 2017). As suggested by France \& Hoover (2002), possible explanations for such reduced rates of divergence include a lower rate of evolution for octocoral mitochondrial genomes (also supported by Shearer et al. 2002) and the presence of a gene, mtMSH, which may code for a mitochondrial DNA mismatch-repair system (Culligan et al. 2000). The purpose of this study is not to try to answer the question of why the interspecific distances of the deep-sea clade within the genus Lebbeus as so low, given the small amount of genetic data available, but it can be concluded that interactions (= gene flow) between populations from the Sea of Okhotsk, the Caribbean and Antarctica are more difficult to imagine than to assume the presence of some mechanism interfering with the standard rates of evolution in the COI mtDNA gene of deep-sea species. In addition, in closely related shallow-water taxa, such as the 


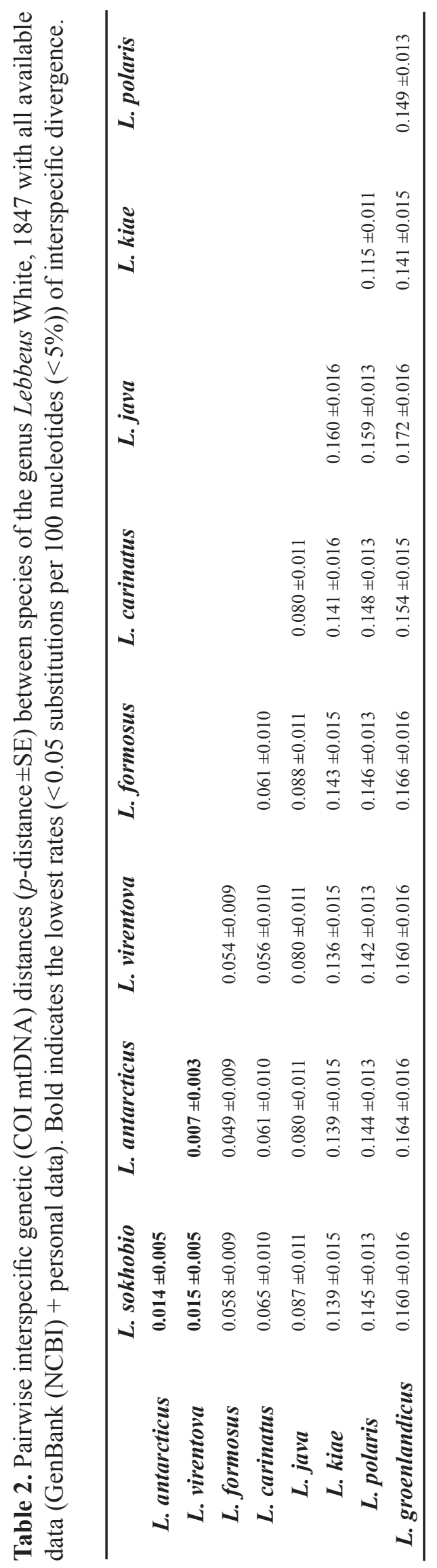




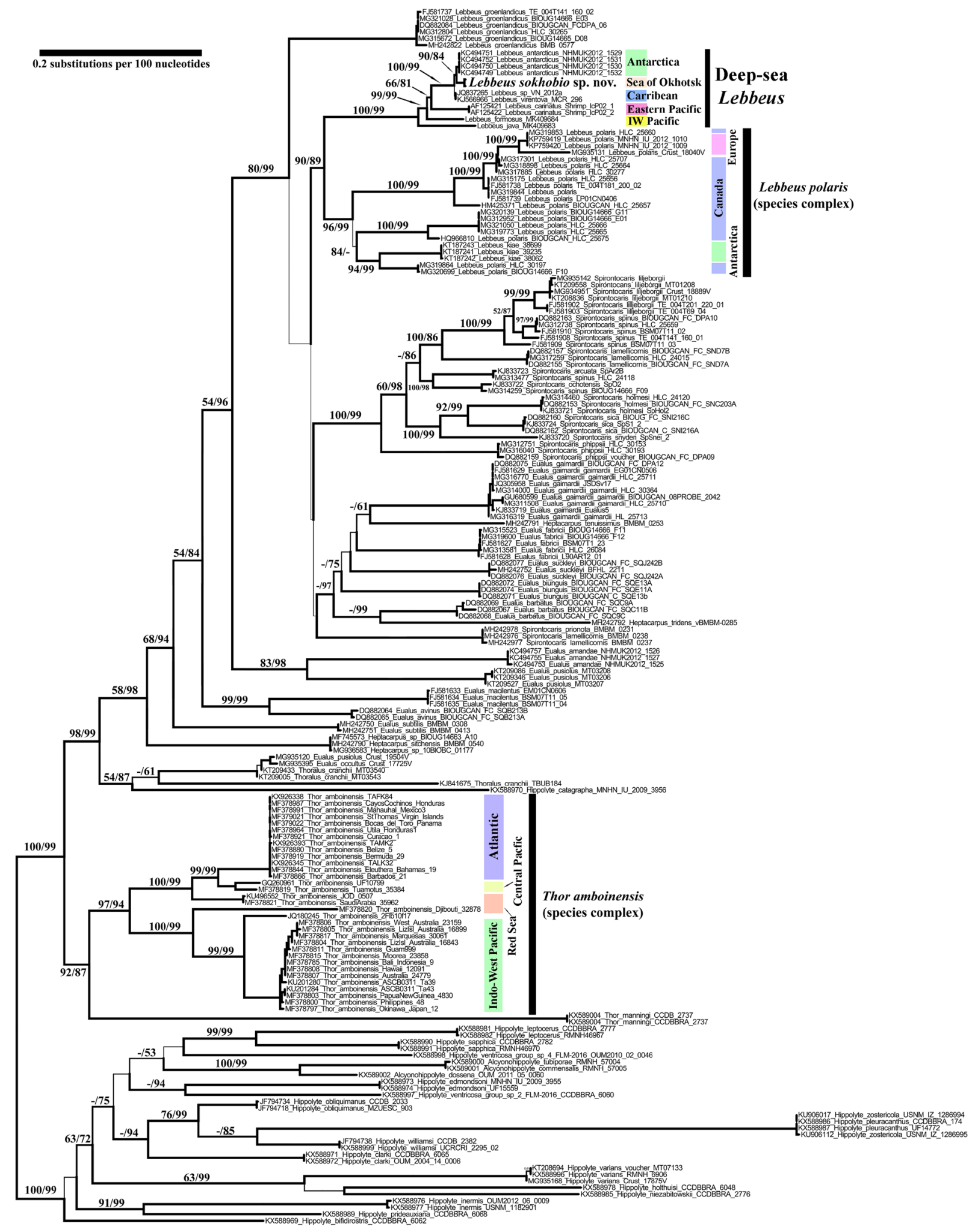

Fig. 7. Phylogenetic relationships within Thoridae (Hippolyte Leach, 1814 as outgroup) based on COI mtDNA gene markers. Bootstrap support $(>50 \%)$ is shown by the numbers along the branches $(\mathrm{BA} / \mathrm{ML}$ analysis). Line thickness is also correlated with support values. 
widely distributed and abundant Thor amboinensis (De Man, 1888) (Thoridae), geographic variability is well reflected in genetic changes (Fig.7; Titus et al. 2018 for T. amboinensis). The Canadian clade of Lebbeus polaris (Sabine, 1824) (see Fig. 7) shows a higher degree of COI mtDNA variability than deep-sea Lebbeus species from different regions of the world. Perhaps the use of other gene markers will allow deep-sea species to be divided more clearly, using molecular genetic methods, but at the moment there is an insufficient amount of genetic information for comparison in international depositories (e.g., GenBank (NCBI) database).

\section{Distribution}

Lebbeus sokhobio sp. nov. is so far known only from the Kuril Basin of the Sea of Okhotsk and is probably endemic for this region in accordance with current knowledge of the limited geographical ranges of species in the genus Lebbeus (e.g., Hayashi 1992; Komai et al. 2004, 2012; Komai 2015; Anosov et al. 2018). In the same bathymetric range along the neighboring Kuril-Kamchatka Trench and the adjacent abyssal plain of the northwestern Pacific, no specimens of this genus were collected, neither during earlier expeditions to the area or as the result of the more recent deep-sea trawling of the KuramBio I-II (Kuril-Kamchatka Biodiversity Studies) Expeditions (Brandt \& Malyutina 2012; Brandt et al. 2016; Malyutina et al. 2018; pers. obs.).

\section{Discussion}

Species of caridean families, including Thoridae, hitherto recorded from abyssal depths (below 3000 m) are presented in Table 1. Among them, Acanthephyridae covers the widest bathymetric range, having been collected from the surface in polar seas to depths of at least $6890 \mathrm{~m}$ (e.g., Kensley et al. 1987; Hendrickx \& Estrada Navarrete 1996; Wicksten 2002; Basher \& Costello 2014; Linley et al. 2018), with some species living within all of this large bathymetric range, e.g., Hymenodora glacialis (Havens \& Rork 1969; Butler 1980; Just 1980; Wasmer 1986; Domansky 1986; Iwasaki \& Nemoto 1987; Hendrickx \& Estrada Navarrete 1996; Wicksten 2002; Basher \& Costello 2014). Representatives of Lebbeus are similarly found in a very wide bathymetric range, from the intertidal zone to the deepest areas (3301-3366 m), in the Sea of Okhotsk.

\section{Acknowledgements}

The material from the Sea of Okhotsk was collected during the SokhoBio 2015 Expedition on the R/V 'Akademik M.A. Lavrentyev' with the financial support of the Russian Science Foundation (project no. 1450-00034); primary sorting and processing of the expedition material was carried out with the financial support of PTJ (German Ministry for Science and Education) grant 03G0857A given to Prof. Dr Angelika Brandt. The processing and preparation of the material in this paper was supported by the Russian Foundation of Basic Research (RFBR) (grants 17-04-00413_A and 18-04-01093_A). Out biogeography and distribution study was supported by the Russian Ministry for Science and Education (project no. 14.616.21.0077). The author is very grateful to the crew of the $\mathrm{R} / \mathrm{V}$ 'Akademik M.A. Lavrentyev' and the scientific team of the SokhoBio 2015 Expedition for sampling and sorting such an extensive expedition material. The author sends special thanks to the specialists of the National Scientific Center of Marine Biology FEB RAS (NSCMB FEB RAS) and especially to Dr Marina Malyutina, Anna Lavrentjeva, $\mathrm{PhD}$ and Anastasia Mayorova, $\mathrm{PhD}$ for sampling, processing, photographing and sending the presented material to the author.

\section{References}

Ahyong S.T. 2010. New species and new records of Caridea (Hippolytidae: Pasiphaeidae) from New Zealand. In: De Grave S. \& Fransen C.H.J.M. (eds) Contributions to Shrimp Taxonomy. Zootaxa 2372 (1): 341-357. https://doi.org/10.11646/zootaxa.2372.1.26 
Alcock A.W. 1901. A Descriptive Catalogue of the Indian Deep-sea Macrura and Anomura in the Indian Museum being a Revised Account of the Deep-sea Species Collected by the Royal Indian Marine Survey Ship "Investigator", Calcutta. Trustees of the Indian Museum, Kolkata.

Allen J.A. \& Butler T.H. 1994. The Caridea (Decapoda) collected by the Mid-Pacific Mountains Expedition, 1968. Pacific Science 48 (4): 410-445.

Amon D.J., Ziegler A., Drazen J.C., Grischenko A., Leitner A., Lindsay D., Voight J.R., Wicksten M., Young C.M. \& Smith C.R. 2017. Megafauna of the UKSRL exploration contract area and eastern Clarion-Clipperton Zone in the Pacific Ocean: Annelida, Arthropoda, Bryozoa, Chordata, Ctenophora, Mollusca. Biodiversity Data Journal 5: e14598. https://doi.org/10.3897/BDJ.5.e14598

Anosov S.E., Ivanov B.G. \& Spiridonov V.A. 2018. Long time hidden: second record in the type locality and redescription of rare caridean shrimp Lebbeus uschakovi (Kobjakova, 1936) (Crustacea: Decapoda: Thoridae). Arthropoda Selecta 27 (1): 37-48.

Arntz W.E. 2003. Expedition Antarktis XIX/5 (Lampos) of RV "Polarstern" in 2002. Alfred Wegener Institut, Bremerhaven, Germany.

Arntz W.E., Gorny M., Soto R., Lardies M.A., Retamal M. \& Wehrtmann I.S. 1999. Species composition and distribution of decapod crustaceans in the waters off Patagonia and Tierra del Fuego, South America. Scientia Marina 63: 303-314.

Baba K., Hayashi K.-I. \& Toriyama M. 1986. Decapod Crustaceans from the Continental Shelf and Slope around Japan. Japan Fisheries Resource Conservation Association, Tokyo.

Basher Z. \& Costello M.J. 2014. Chapter 5.22. Shrimps (Crustacea: Decapoda). In: De Broyer C., Koubbi P., Griffiths H.J., Raymond B., d'Udekem d'Acoz, C., Van de Putte A.P., Danis B., David B., Grant S., Gutt J., Held C., Hosie G., Huettmann F., Post A. \& Ropert-Coudert Y. (eds) Biogeographic Atlas of the Southern Ocean. Scientific Committee on Antarctic Research, Cambridge.

Beltenev V., Ivanov V., Rozhdestvenskaya I., Cherkashev G., Stepanov T., Shilov V., Davydov M., Laiba A., Kaylio V., Narkevsky E., Pertsev A., Dobretzova I., Gustaytis A., Popva Y., Amplieva Y., Evrard C., Moskalev L. \& Gebruk A. 2009. New data about hydrothermal fields on the Mid-Atlantic Ridge between $118-148^{\circ} \mathrm{N}$ : $32^{\text {nd }}$ Cruise of R/V Professor Logatchev. InterRidge News 18: 13-17.

Birštein Y.A. \& Vinogradov L.G. 1951. New and rare Decapoda from the Sea of Okhotsk and Kurilean waters. Doklady Akademii Nauk SSSR 79: 357-360. [In Russian]

Birštein Y.A. \& Vinogradov L.G. 1953. New data on the decapod fauna of the Bering Sea. Zoologicheskyi Zhurnal 32: 215-228. [In Russian]

Blagodatski A., Cherepanov V., Koval A., Kharlamenko V.I., Khotimchenko Y.S. \& Katanaev V.L. 2017. High-throughput targeted screening in triple-negative breast cancer cells identifies Wnt-inhibiting activities in Pacific brittle stars. Scientific Reports 7 (1): e11964.

https://doi.org/10.1038/s41598-017-12232-7

Boschi E.E., Iorio M.I. \& Fischbach K. 1981. Distribución y abundancia de los crustaceos decápodos capturados en las campañas de los B/I "Walther Herwig" y "Shinkai Maru" en el Mar Argentino, 19781979. In: Angelescu V. (ed.) Campañas de Investigación pesquera realizadas en el Mar Argentino por los B/I "Shinkai Maru" $y$ "Walther Herwig" y el B/P "Marburg",Años 1978 y 1979. Contribuciones INIDEP 383: 233-253. Instituto Nacional de Investigación y Desarrollo Pesquero, Mar del Plata, Argentina.

Bowman T.E. \& Manning R.B. 1972. Two Arctic bathyal crustaceans: the shrimp Bythocaris cryonesus new species, and the amphipod Eurythenes gryllus, with in situ photographs from Ice Island T-3. Crustaceana 23: 187-201. https://doi.org/10.1163/156854072X00363 
Brandt A. \& Malyutina M. 2012. The German-Russian Deep-sea Expedition KuramBio (Kurile Kamchatka Biodiversity Study): to the Kurile Kamchatka Trench and Abyssal Plain on Board of the R/V Sonne, 223 ${ }^{\text {rd }}$ Expedition. Online Cruise Report. http://doi.org/10.2314/GBV:741102293

Brandt A. \& shipboard scientific party. 2016. RV Sonne SO-250 Cruise Report/Fahrtbericht, Tomakomai-Yokohama (Japan) 16.08-26.09.2016. SO-250 KuramBio II (Kuril Kamchatka Biodiversity Studies). University of Hamburg, Center of Natural History (CeNak), Zoological Museum Hamburg and shipboard scientific party, Hamburg.

Bražhnikov V. 1907. Material representing the fauna of the Eastern Russian Seas collected by the Schooner "Storosh" in 1899-1902. Zapiski Imperatorskoi Akademii Nauk 20 (8): 1-185. [In Russian]

Burukovsky R.N. 2003. Shrimps of the Family Nematocarcinidae. Kaliningrad State Technical University, Kaliningrad. [In Russian]

Burukovsky R.N. 2006. Systematics of shrimps of the genus Nematocarcinus (Decapoda, Nematocarcinidae). Description of the type specimen, $N$. paucidentatus and some unidentified species of the family Nematocarcinidae from the collection of the British Museum (samples from the "Challenger"). Zoologicheskyi Zhurnal 85: 896-900. [In Russian]

Butler T.H. 1980. Shrimps of the Pacific Coast of Canada. Canadian Bulletin of Fisheries and Aquatic Sciences 202: 1-280.

Cardoso I.A. 2013. On some rare Oplophoridae (Caridea, Decapoda) from the South Mid-Atlantic Ridge. Latin American Journal of Aquatic Research 41: 209-216.

https://doi.org/10.3856/vol41-issue2-fulltext-1

Cardoso I.A. \& Young P.S. 2005. Deep sea Oplophoridae (Crustacea, Caridea) from the southwestern Brazil. Zootaxa 1031 (1): 1-74. https://doi.org/10.11646/zootaxa.1031.1.1

Chace F.A. Jr. 1939. Reports on the scientific results of the first Atlantis expedition to the West Indies, under the joint auspices of the University of Havana and Harvard University. Preliminary descriptions of one new genus and seventeen new species of decapod and stomatopod Crustacea. Memorias de la Sociedad Cubana de Historia Natural 13: 31-54.

Chace F.A. Jr. 1940. Plankton of the Bermuda Oceanographic Expeditions. IX. The bathypelagic caridean Crustacea. Zoologica (N.S.) 25: 117-209.

Chace F.A. Jr. 1984. The caridean shrimps (Crustacea: Decapoda) of the Albatross Philippine Expedition, 1907-1910, Part 2: families Glyphocrangonidae and Crangonidae. Smithsonian Contributions to Zoology 397: 1-63.

Chace F.A. Jr. 1986. The caridean shrimps (Crustacea: Decapoda) of the "Albatross" Philippine Expedition, 1907-1910, Part 4: Families Oplophoridae and Nematocarcinidae. Smithsonian Contribution to Zoology 432: 1-82.

Chan T.-Y. \& Komai T. 2017. A new shrimp species of the genus Lebbeus White, 1847 (Crustacea: Deacpoda: Caridea: Thoridae) from a deep-sea cold seep site off southwestern Taiwan. Zootaxa 4238 (3): 426-432. https://doi.org/10.11646/zootaxa.4238.3.9

Chan T.-Y. \& Yu H.-P. 1986. The deep-sea shrimps of the family Oplophoridae (Crustacea: Decapoda) from Taiwan. Asian Marine Biology 3: 89-99.

Chang S.-C., Komai T. \& Chan T.-Y. 2010. First record of the hippolytid shrimp genus Lebbeus White, 1847 (Decapoda: Caridea) from Taiwan, with the description of three new species. Journal of Crustacean Biology 30 (4): 727-744. https://doi.org/10.1651/10-3283.1

Chow S., Okazaki M., Takeda M. \& Kubota T. 2000. A rare abyssal shrimp, Galatheocaris abyssalis, found in the stomach of a lancetfish. Crustaceana 73 (2): 243-246. https://doi.org/10.1163/156854000504192 
Cleva R. 1994. Some Australian Stylodactylidae (Crustacea: Decapoda), with description of two new species. The Beagle 11: 53-64. Available from https://biodiversitylibrary.org/page/55849025 [accessed 28 Jan. 2020].

Company J.B., Maiorano P., Tselepides A., Politou C.Y., Plaity W., Rotllant G. \& Sarda F. 2004. Deepsea decapod crustaceans in the western and central Mediterranean Sea: preliminary aspects of species distribution, biomass and population structure. Scientia Marina 68: 73-86.

Crosnier A. 1987. Oplophoridae (Crustacea Decapoda) récoltés de 1971 à 1982 par les navires françaises dans l'océan Indien occidental sud. Bulletin du Muséum national d'histoire naturelle, Série 4, Section A 9: 695-726.

Crosnier A. 1988. Sur la présence de Parapasiphae compta Smith, 1884, dans l'Atlantique oriental (Crustacea Decapoda Pasiphaeidae). Bulletin du Muséum national d'histoire naturelle, Série 4, Section A 10: 799-803.

Crosnier A. \& Forest J. 1968. Note preliminaire sur les carides recueillis par 1' "Ombango" au large du plateau continental du Gabon a l'Angola (Crustacea Decapoda Natantia). Bulletin du Muséum national d'histoire naturelle, Série 239 (6): 1123-1147.

Crosnier A. \& Forest J. 1973. Les crevettes profondes de 1'Atlantique oriental tropical. Faune Tropicale, O.R.S.T.O.M. 19: 1-409.

Culligan K.M., Meyer-Gauen G., Lyons-Weiler J. \& Hays J.B. 2000. Evolutionary origin, diversification and specialization of eukaryotic MutS homolog mismatch repair proteins. Nucleic Acids Research 28 (2): 463-471. https://doi.org/10.1093/nar/28.2.463

De Grave S. \& Fransen C.H.J.M. 2011. Carideorum catalogus: the recent species of the dendrobranchiate, stenopodidean, procarididean and caridean shrimps. Zoologische Mededelingen 85: 195-588.

De Man J.G. 1920. The Decapoda of the Siboga Expedition, Part IV. Families Pasiphaeidae, Stylodactylidae, Hoplophoridae, Nematocarcinidae, Thalassocaridae, Pandalidae, Psalidopidae, Gnathophyllidae, Processidae, Glyphocrangonidae and Crangonidae. Siboga-Expeditie Monographie 39A: $1-318$.

Derjugin K.M. \& Kobjakova Z.I. 1935. Zur Dekapodenfauna des japonischen Meeres. Zoologischer Anzeiger 112: 141-147.

Doflein F. \& Balss H. 1912. Die Dekapoden und Stomatopoden der Hamburger Magalhaenischen Sammelreise 1892/93. Mitteilungen aus dem Naturhistorischen Museum in Hamburg 29: 25-44. Available from https://biodiversitylibrary.org/page/29529907 [accessed 20 Jan. 2020].

Domanski P. 1986. The near-bottom shrimp faunas (Decapoda: Natantia) at two abyssal sites in the Northeast Atlantic Ocean. Marine Biology 93: 171-180.

Fabri M.-C., Bargain A., Briand P., Gebruk A., Fouquet Y., Morineaux M. \& Desbruyeres D. 2011. The hydrothermal vent community of a new deep-sea file, Ashadze-1, $128^{\circ} 58^{\prime} \mathrm{N}$ on the Mid-Atlantic Ridge. Journal of the Marine Biological Association of the United Kingdom 91 (1): 1-13.

https://doi.org/10.1017/S0025315410000731

Faxon W. 1893. Reports on the dredging operations off the west coast of Central America to the Galapagos, to the west coast of Mexico, and in the Gulf of California, in charge of Alexander Agassiz, carried on by the U.S. Fish Commission steamer "Albatross", during 1891, Lieut. Commander Z.L. Tanner, U.S.N., commanding. VI. Preliminary descriptions of new species of Crustacea. Bulletin of the Museum of Comparative Zoology at Harvard College 24: 149-220.

Available from https://biodiversitylibrary.org/page/28859557 [accessed 3 Feb. 2020]. 
Folmer O., Black M., Hoeh W., Lutz R. \& Vrijenhoek R. 1994. DNA primers for amplification of mitochondrial cytochrome $\mathrm{C}$ oxidase subunit I from diverse metazoan invertebrates. Molecular Marine Biology and Biotechnology 3: 294-299.

Foxton P. 1970. The vertical distribution of pelagic decapods (Crustacea: Natantia) collected on the SOND cruise, 1965. I. The Caridea. Journal of the Marine Biological Association of the United Kingdom 50 (4): 939-960. https://doi.org/10.1017/S0025315400005907

Foxton P. 1971. A new species of the genus Acanthephyra (Crustacea: Natantia): first discovered and described in ms notes by Dr Stanley W. Kemp. Journal of the Marine Biological Association of the United Kingdom 51 (1): 33-41. https://doi.org/10.1017/S0025315400006421

France S.C. \& Hoover L.L. 2002. DNA sequences of the mitochondrial COI gene have low levels of divergence among deep-sea octocorals (Cnidaria: Anthozoa). Hydrobiologia 471 (1-3): 149-155. https://doi.org/10.1023/A:1016517724749

Fransen C.H.J.M. 1997. Lebbeus africanus spec. nov., a new shrimp (Crustacea, Decapoda, Caridea, Hippolytidae) from Mauritanian waters, with redescriptions of four other species in the genus. Zoologische Mededelingen 71 (20): 231-260.

Gerringer M.E., Linley T.D., Jamieson A.J., Goetze E. \& Drazen J.C. 2017. Pseudoliparis swirei sp. nov.: a newly-discovered hadal snailfish (Scorpaeniformes: Liparidae) from the Mariana Trench. Zootaxa 4358 (1): 161-177. https://doi.org/10.11646/zootaxa.4358.1.7

Gore R.H. 1985. Some rare species of abyssobenthic shrimp (families Crangonidae, Glyphocrangonidae and Nematocarcinidae) from the Venezuela Basin, Caribbean Sea (Decapoda, Caridea). Crustaceana 48 (3): 269-285. https://doi.org/10.1163/156854085X00981

Gorny M. 1992. Untersuchungen zur Ökologie antarktischer Garnelen (Decapoda, Natantia). PhD Dissertation, University of Bremen, Germany.

Gorny M. 1999. On the biogeography and ecology of the Southern Ocean decapod fauna. Scientia Marina 63: 367-382.

Gutt J., Gorny M. \& Arntz W. 1991. Spatial distribution of Antarctic shrimps (Crustacea, Decapoda) by underwater photography. Antarctic Science 3 (4): 363-369.

Gutt J., Ekau W. \& Gorny M. 1994. New results on the fish and shrimp fauna of the Weddell Sea and Lazarev Sea (Antarctica). Proceedings of the NIPR Symposium on Polar Biology (15 $5^{\text {th }}$ Symposium on Polar Biology) 7: 91-102.

Hale H.M. 1941. Decapoda Crustacea. British, Australian and New Zealand Antarctic Research Expedition 1929-1931, Reports - Series B (Zoology and Botany) 4: 257-285.

Hanamura Y. \& Takeda M. 1996. Establishment of a new genus Bathystylodactylus (Crustacea: Decapoda: Stylodactylidae), with description of a new species from northwestern Pacific. Zoological Science 13 (6): 929-934. https://doi.org/10.2108/zsj.13.929

Havens A.D. \& Rork W.L. 1969. Hymenodora glacialis (Decapoda: Natantia) from the Arctic Basin. Bulletin of the Southern California Academy of Sciences 68: 19-29.

Available from https://biodiversitylibrary.org/page/49043145 [accessed 28 Jan. 2020].

Hayashi K. 1992. Studies on the hippolytid shrimps from Japan - VIII. The genus Lebbeus White. Journal of the Shimonoseki College of Fisheries 40: 107-138.

Hayashi K.I. \& Miyake S. 1969. Bathypelagic caridean shrimps collected by "Koyo Maru" during the International Indian Ocean Expedition, Ohmu. Occasional Papers of the Zoological Laboratory, Faculty of Agriculture, Kyushu University, Fukuoka 2: 59-77. 
Hayashi K.-I. \& Okuno J. 1997. Two associated hippolytids, Lebbeus comanthi sp. nov. and Lebbeus balssi Hayashi (Decapoda, Caridea, Hippolytidae) from Japan. Journal of the Shimonoseki College of Fisheries 46: 47-56.

Hebert P.D.N., Cywinska A., Ball S.L. \& De Waard J.R. 2003. Biological identifications through DNA barcodes. Proceedings of the Royal Society of London B 270: 313-322.

https://doi.org/10.1098/rspb.2002.2218

Hendrickx M.E. \& Estrada Navarrete F.D. 1996. Los Camarones pelágicos del Pacifico mexicano (Dendrobranchiata y Caridea). Instituto de Ciencias de Mar y Limnologia, Universidad Nacional Autónoma de México, Mazatlan, Mexico.

Hendrickx M.E. \& Papiol V. 2015. Insights on the biology and ecology of the deep-water shrimp Parapontophilus occidentalis (Faxon, 1893) (Crustacea, Caridea, Crangonidae) in the eastern Pacific with notes on its morphology. Zootaxa 4007 (3): 370-388. https://doi.org/10.11646/zootaxa.4007.3.4

Hessler R.R., Ingram L.C., Yayanos A.A. \& Burnett R.B. 1978. Scavenging amphipods from the floor of the Philippine Trench. Deep Sea Research 25 (11): 1029-1047.

https://doi.org/10.1016/0146-6291(78)90585-4

Hiller-Adams P. \& Case J.F. 1985. Optical parameters of the eyes of some benthic decapods as a function of habitat depth (Crustacea, Decapoda). Zoomorphology 105 (2): 108-113.

https://doi.org/10.1007/BF00312145

Holthuis L.B. 1951. The caridean Crustacea of tropical west Africa. Atlantide Report 2: 7-187.

Holthuis L.B. 1971. Biological results of the University of Miami deep-sea expeditions. 75. The Atlantic shrimps of the deep-sea genus Glyphocrangon A. Milne Edwards, 1881. Bulletin of Marine Science 21: 267-373.

Iwasaki N. \& Nemoto T. 1987. Distribution and community structure of pelagic shrimps in the Southern Ocean between $150^{\circ} \mathrm{E}$ and $115^{\circ} \mathrm{E}$. Polar Biology 8 (2): 121-128.

Jamieson A.J., Fujii T., Solan M., Matsumoto A.K., Bagley P.M. \& Priede I.G. 2009. First findings of decapod Crustacea in the hadal zone. Deep Sea Research Part I: Oceanographic Research Papers 56: 641-647. https://doi.org/10.1016/j.dsr.2008.11.003

Jonsson L.G., Lundälv T. \& Johannesson K. 2001. Symbiotic associations between anthozoans and crustaceans in a temperate coastal area. Marine Ecology Progress Series 209: 189-195.

https://doi.org/10.3354/meps209189

Just J. 1980. Abyssal and deep bathyal Malacostraca (Crustacea) from the Polar Sea. Videnskabelige Meddelelser fra Dansk naturhistorisk Forening 142: 161-177.

Kemp S.W. 1906. On the occurrence of the genus Acanthephyra in deep water off the west coast of Ireland. Scientific Investigations: Fisheries Branch, Ireland 1905 (1): 3-28.

Kensley B., Tranterm H.A. \& Griffin D.J.G. 1987. Deepwater decapod Crustacea from eastern Australia (Penaeidae and Caridea). Records of the Australian Museum 39: 263-331.

https://doi.org/10.3853/j.0067-1975.39.1987.171

Kikuchi T. \& Omori M. 1985. Vertical distribution and migration of oceanic shrimps at two locations off the Pacific coast of Japan. Deep Sea Research A 32 (7): 837-851.

https://doi.org/10.1016/0198-0149(85)90119-0

Kim J.N., Hayashi K., Natsukari Y. \& Yoshida K. 2000. Abyssobenthic shrimps (Crustacea, Decapoda, Penaeidea and Caridea) from the Northwest Pacific collected by RV Soyo-maru. Biogeography 2: 3-20. 
Knowlton N. \& Weigt L.A. 1998. New dates and new rates for divergence across the Isthmus of Panama. Proceedings of the Royal Society of London B 265: 2257-2263. https://doi.org/10.1098/rspb.1998.0568

Knowlton N., Weigt L.A., Solorzano L.A., Mills D.K. \& Bermingham E. 1993. Divergence in proteins, mitochondrial DNA and reproductive compatibility across the Isthmus of Panama. Science 260 (5114): 1629-1632. https://doi.org/10.1126/science.8503007

Kobayashi H., Hatada Y., Tsubouchi T., Nagahama T. \& Takami H. 2012. The hadal amphipod Hirondellea gigas possessing a unique cellulase for digesting wooden debris buried in the deepest seafloor. PLoS One 7 (8): e42727. https://doi.org/10.1371/journal.pone.0042727

Kobjakova Z.I. 1936. Zoogeographical review of the Decapoda fauna from the Okhotsk and Japanese Seas. Transactions of the Natural Society of Leningrad 65: 185-228. [In Russian]

Kobjakova Z.I. 1937. Desjatinoge raki (Decapoda) Okhotskogo i Japonskogo morei [Systematische Uebersicht der Dekapoden aus dem Ochotskischen und Japanischen Meere]. Uchenye Zapiski Leningradskogo Universiteta 15: 93-154. [In Russian with German summary]

Kobjakova Z.I. 1955. New species of Crustacea, Decapoda from the southern part of Kurile Sakhalin region. Transactions of the Institute of Zoology of the Academy of Sciences of USSR 18: 235-242. [In Russian]

Kobjakova Z.I. 1958. Decapoda from South Kurile Islands. Issledovaniya Dalnevostochnyh Morei SSSR 5: 220-248. [In Russian]

Kobjakova Z.I. 1962. Some rare and new species of Decapoda, Malacostraca, from Kurile Islands. Issledovaniya Dalnevostochnyh Morei SSSR 8: 243-247. [In Russian]

Kobjakova Z.I. 1967. Decapoda (Crustacea, Decapoda) from the Possjet Bay (the Sea of Japan). Explorations of the Fauna of the Seas V (XIII). Biocoenoses of the Possjet Bay of the Sea of Japan (Hydrobiological Investigations by Means of Aqualungs): 230-247. Academy of Sciences of the USSR, Moscow. [In Russian]

Komai T. 1991. Deep-sea decapod crustaceans from the Pacific coast of eastern Hokkaido, northern Japan (Crustacea, Decapoda, Penaeidea and Caridea). Report of the North Japan Sub-Commitee for Bottom Fish, Research Committee for Fishery Resources 24: 55-96.

Komai T. 1994. Deep-sea shrimps of the genus Pandalopsis (Decapoda: Caridea: Pandalidae) from the Pacific coast of eastern Hokkaido, Japan, with the descriptions of two new species. Journal of Crustacean Biology 14 (3): 538-559. https://doi.org/10.1163/193724094X00119

Komai T. 1997. Revision of Argis dentata and related species (Decapoda: Caridea: Crangonidae), with description of a new species from the Okhotsk Sea. Journal of Crustacean Biology 17 (1): 135-161. https://doi.org/10.1163/193724097X00160

Komai T. 2004. A review of the Indo-West Pacific species of the genus Glyphocrangon A. MilneEdwards, 1881 (excluding the G. caeca Wood Mason, 1891 species group) (Crustacea: Decapoda: Caridea: Glyphocrangonidae). In: Marshall B. \& Richer de Forges B. (eds) Tropical Deep Sea Benthos, Vol. 23. Memoires du Museum national d'histoire naturelle 191: 375-610.

Komai T. 2008. A world-wide revision of species of the deep-water crangonid genus Parapontophilus Christoffersen, 1988 (Crustacea, Decapoda, Caridea), with descriptions of ten new species. Zoosystema 30: 261-332.

Komai T. 2011. Deep-sea shrimps and lobsters (Crustacea: Decapoda: Dendrobranchiata and Pleocyemata) from the Sagami Sea and Izu Islands, Central Japan. Memoirs of the National Science Museum, Tokyo 47: 279-337. 
Komai T. 2013. A new species of the hippolytid shrimp genus Lebbeus (Crustacea: Decapoda: Caridea) from lower bathyal zone in the Izu Islands, Central Japan. Journal of the Natural History Museum and Institute, Chiba 12 (2): 81-89.

Komai T. 2015. Reinstatement and redescription of Lebbeus armatus (Owen, 1839), long synonymized with L. groenlandicus (Fabricius, 1775), and description of one new species from the southwestern Sea of Okhotsk, Hokkaido, Japan (Crustacea: Decapoda: Caridea: Thoridae). Zootaxa 3905 (4): 451-473. https://doi.org/10.11646/zootaxa.3905.4.1

Komai T. \& Amaoka K. 1991. A new species of the genus Sclerocrangon from Urup Island, Kurile Islands and east of Hokkaido (Crustacea, Decapoda, Crangonidae). Proceedings of the Japanese Society of Systematic Zoology 44: 26-37.

Komai T. \& Chan T.-Y. 2009. New genus and species of Crangonidae (Decapoda: Caridea) with a large plate-like eye from the abyssal zone off Taiwan, Northwestern Pacific. Journal of Crustacean Biology 29 (2): 254-265. https://doi.org/10.1651/08-3080R.1

Komai T. \& Hibino M. 2019. Three new species of the pandalid shrimp genus Pandalopsis Spence Bate, 1888 (Crustacea: Decapoda: Caridea) from the southwestern Sea of Okhotsk, with supplemental note on P. glabra Kobjakova, 1936. Zootaxa 4545 (1): 1-31. https://doi.org/10.11646/zootaxa.4545.1.1

Komai T. \& Komatsu H. 2009. Deep-sea shrimps and lobsters (Crustacea: Decapoda: Penaeidea, Caridea, Polychelidea) from northern Japan, collected during the Project "Research on Deep-sea Fauna and Pollutants off Pacific Coast of Northern Honshu, Japan, 2005-2008". National Museum of Nature and Science Monographs 39: 495-580.

Komai T. \& Komatsu H. 2016. Additional records of deep-water shrimps (Crustacea, Decapoda, Dendrobranchiata and Caridea) from off Northeastern Japan. Bulletin of the National Museum of Nature and Science, Series A, Zoology 42 (1): 23-48.

Komai T. \& Matsuzaki K. 2016. Two deep-sea decapod crustaceans collected off eastern Hokkaido, Japan: Sclerocrangon rex n. sp. (Caridea: Crangonidae) and Munidopsis verrilli Benedict, 1902 (Anomura: Munidopsidae). Zootaxa 4162 (1): 92-106. https://doi.org/10.11646/zootaxa.4162.1.4

Komai T. \& Segonzac M. 2003. Review of the hydrothermal vent shrimp genus Mirocaris, redescription of $M$. fortunata and reassessment of the taxonomic status of the family Alvinocarididae (Crustacea: Decapoda: Caridea). Cahiers de Biologie Marine 44: 199-215.

https://doi.org/10.21411/CBM.A.B886EA84

Komai T. \& Segonzac M. 2005. A revision of the genus Alvinocaris Williams and Chace (Crustacea: Decapoda: Caridea: Alvinocarididae), with descriptions of a new genus and a new species of Alvinocaris. Journal of Natural History 39: 1111-1175. https://doi.org/10.1080/00222930400002499

Komai T. \& Segonzac M. 2008. Taxonomic review of the hydrothermal vent shrimp genera Rimicaris Williams \& Rona and Chorocaris Martin \& Hessler (Crustacea: Decapoda: Caridea: Alvinocarididae). Journal of Shellfish Research 27 (1): 21-41.

https://doi.org/10.2983/0730-8000(2008)27[21:TROTHV]2.0.CO;2

Komai T. \& Yakovlev Y.I. 2000. Decapod crustaceans collected during the Biological Expedition to the Kamchatka Peninsula and the North Kuril Islands in 1997. Natural History Research, Special Issue 7: 301-322.

Komai T., Hayashi K. \& Kohtsuka H. 2004. Two new species of the shrimp genus Lebbeus White from the Sea of Japan, with redescription of Lebbeus kuboi Hayashi (Decapoda: Caridea: Hippolytidae). Crustacean Research 33: 103-125. https://doi.org/10.18353/crustacea.33.0_103 
Komai T., Shank T.M. \& Van Dover C.L. 2005. A new species of Alvinocaris (Crustacea: Decapoda: Caridea: Alvinocaridae) and a new record of A. muricola from methane seeps on the Blake Ridge Diapir, north-western Atlantic. Zootaxa 1019 (1): 27-42. https://doi.org/10.11646/zootaxa.1019.1.2

Komai T., Martin J.W., Zala K., Tsuchida S. \& Hashimoto J. 2006. A new species of Mirocaris (Crustacea: Decapoda: Caridea: Alvinocarididae) associated with hydrothermal vents on the Central Indian Ridge, Indian Ocean. Scientia Marina 70: 109-119.

Komai T., Giere O. \& Segonzac M. 2007. New record of alvinocaridid shrimps (Crustacea: Decapoda: Caridea) from hydrothermal vent fields on the southern Mid-Atlantic Ridge, including a new species of the genus Opaepele. Species Diversity 12: 237-253. https://doi.org/10.12782/specdiv.12.237

Komai T., Tsuchida S. \& Segonzac M. 2012. Records of species of the hippolytid genus Lebbeus White, 1847 (Crustacea: Decapoda: Caridea) from hydrothermal vents in the Pacific Ocean, with descriptions of three new species. Zootaxa 3241 (1): 35-63. https://doi.org/10.11646/zootaxa.3241.1.2

Komai T., Matsuzaki K. \& Hibino M. 2016. Rediscovery and redescription of a deep-sea shrimp Lebbeus longidactylus (Kobjakova, 1936) (Crustacea: Decapoda: Caridea: Thoridae) based on material from the Nemuro Strait, southwestern Sea of Okhotsk. Zootaxa 4175 (4): 390-400.

https://doi.org/10.11646/zootaxa.4175.4.8

Komai T., Marin I. \& Kakui K. 2017. Rediscovery and redescription of the abyssal squat lobster Munidopsis petalorhyncha Baba, 2005 (Crustacea: Decapoda: Munidopsidae) from the northwest Pacific. Zootaxa 4226 (1): 93-102. https://doi.org/10.11646/zootaxa.4226.1.4

Komai T., Ohtsuka S., Yamaguchi S. \& Nakaguchi K. 2018. New records of six deep-sea caridean shrimps (Crustacea: Decapoda) from the Ryukyu Islands and its adjacent waters, southwestern Japan. Zootaxa 4457 (1): 114-128. https://doi.org/10.11646/zootaxa.4457.1.5

Komai T., Chang S.-C. \& Chan T.-Y. 2019. A new deep-sea species of the caridean shrimp genus Lebbeus White, 1847 (Crustacea: Decapoda: Thoridae) from southern Java, Indonesia. Raffles Bulletin of Zoology 67: 150-159. https://doi.org/10.26107/RBZ-2019-0012

Krygier E.E. \& Pearcy W.G. 1981. Vertical distribution and biology of pelagic decapod crustaceans off Oregon. Journal of Crustacean Biology 1 (1): 70-95. https://doi.org/10.2307/1548206

Kurata H. 1964a. Larvae of decapod Crustacea of Hokkaido. 3. Pandalidae. Bulletin of the Hokkaido Regional Fisheries Research Laboratory 28: 23-24. [In Japanese with English summary]

Kurata H. 1964b. Larvae of decapod Crustacea of Hokkaido. 4. Crangonidae and Glyphocrangonidae. Bulletin of the Hokkaido Regional Fisheries Research Laboratory 28: 35-50. [In Japanese with English summary]

Lefébure T., Douady C.J., Gouy M. \& Gibert J. 2006a. Relationships between morphological taxonomy and molecular divergence within Crustacea: proposal of a molecular threshold to help species delimitation. Molecular Phylogenetics and Evolution 40 (2): 435-447. https://doi.org/10.1016/j.ympev.2006.03.014

Lefébure T., Douady C.J., Gouy M., Trontelj P., Briolay J. \& Gibert J. 2006b. Phylogeography of a subterranean amphipod reveals cryptic diversity and dynamic evolution in extreme environments. Molecular Ecology 15: 1797-806. https://doi.org/10.1111/j.1365-294X.2006.02888.x

Linley T.D., Craig J., Jamieson A.J. \& Priede I.G. 2018. Bathyal and abyssal demersal bait-attending fauna of the Eastern Mediterranean Sea. Marine Biology 165 (10): 159.

https://doi.org/10.1007/s00227-018-3413-0

Liu J. \& Zhang H. 2018. DNA barcoding for species identification in deep-sea clams (Mollusca: Bivalvia: Vesicomyidae). Mitochondrial DNA Part A 29 (8): 1165-1173.

https://doi.org/10.1080/24701394.2018.1424843 
Lörz A.N., Berkenbusch K., Nodder S., Ahyong S., Bowden D., McMillan P., Gordon D., Mills S. \& Mackay K. 2012. A review of deep-sea benthic biodiversity associated with trench, canyon and abyssal habitats below $1500 \mathrm{~m}$ depth in New Zealand waters. New Zealand Aquatic Environment and Biodiversity Report 92: 1-133.

Lovrich G.A., Romero M.C., Tapella F. \& Thatje S. 2005. Distribution, reproductive and energetic conditions of decapod crustaceans along the Scotia Arc (Southern Ocean). Scientia Marina 69 (Suppl. 2): 183-193.

Makarov V.V. 1938. Rakoobraznye. Anomura. In: Shtakel'berg A.A. (ed.) Fauna SSSR, Series 1610 (3): 1-324. Akademie Nauk SSSR. [In Russian]

Makarov V.V. 1962. Fauna of USSR. Volume 10 (3). Crustacea. Anomura. [English version, Israel Program for Scientific Translation, Jerusalem]

Makarov R.R. 1966. Lichinki Krevetok, Rakov Otshelnikov i Krabov Zapadno-Kamchatskogo Shel'fa $i$ ikh Raspredelenie [Larvae of Shrimps, Hermit Crabs and Crabs from Western Kamchatka Shelf and their Distribution]. Nauka, Moscow. [In Russian]

Malyutina M.V., Chernyshev A.V. \& Brandt A. 2018. Introduction to the SokhoBio (Sea of Okhotsk Biodiversity Studies) expedition 2015. Deep Sea Research II 154: 1-9.

https://doi.org/10.1016/j.dsr2.2018.08.012

Marin I.N. 2013. Atlas of Decapod Crustaceans of Russia. KMK Scientific Press, Moscow.

Marin I.N. 2017. COXI based phylogenetic analysis of Caucasian clade of European Troglocaris s.1. (Crustacea: Decapoda: Atyidae) with the suggestion of a new taxonomic group structure. Biosystems Diversity 25 (4): 323-327. https://doi.org/10.15421/011749

Marin I. 2018. Deep water decapod crustaceans (Crustacea: Decapoda) collected by SokhoBio 2015 Expedition from bathyal and abyssal waters of the Sea of Okhotsk and adjacent NW Pacific with the re-description of Calocarides okhotskensis Sakai, 2011 (Axiidae). Deep Sea Research II 154: 330-341. https://doi.org/10.1016/j.dsr2.2018.04.007

Marin I. 2020. Northern unicorns of the depths: diversity of the genus Munidopsis Whiteaves, 1874 (Decapoda: Anomura: Munidopsidae) in the northwestern Pacific Ocean, with descriptions of three new species along the Russian coast. Progress in Oceanography [online]: 1-53.

https://doi.org/10.1016/j.pocean.2020.102263

Marin I.N., Ng P.K.L. \& Anosov S.E. 2015. A new record of the Japanese Longhorn decorator crab Chorilia japonica (Miers, 1879) (Crustacea, Brachyura, Epialtidae) in the western part of Bering Sea the first record of the species and genus for Russian fauna. Arthropoda Selecta 24 (2): 185-188.

Martin J.W. \& Christiansen J.C. 1995. A new species of the shrimp genus Chorocaris Martin and Hessler, 1990 (Crustacea, Decapoda, Bresiliidae) from hydrothermal vent fields along the Mid-Atlantic Ridge. Proceedings of the Biological Society of Washington 108 (2): 220-227.

Available from https://biodiversitylibrary.org/page/34572050 [accessed 20 Jan. 2020].

Martin J.W. \& Haney T.A. 2005. Decapod crustaceans from hydrothermal vents and cold seeps: a review through 2005. Zoological Journal of the Linnean Society 145 (4): 445-522.

https://doi.org/10.1111/j.1096-3642.2005.00178.x

Martin J.W. \& Hessler R.R. 1990. Chorocaris vandoverae, a new genus and species of hydrothermal vent shrimp (Crustacea, Decapoda, Bresiliidae) from the western Pacific. Contributions in Science, Natural History Museum of Los Angeles County 417: 1-11. 
Matsuzaki K., Hibino M. \& Komai T. 2015. A new species of the caridean shrimp genus Lebbeus White, 1847 (Crustacea: Decapoda: Thoridae) from the southwestern Sea of Okhotsk, Hokkaido, Japan. Zootaxa 4032 (3): 309-318. https://doi.org/ 10.11646/zootaxa.4032.3.6

Mezhov B.V. 1993. Three new species of Macrostylis G.O. Sars, 1864 (Crustacea: Isopoda: Asellota: Macrostylidae) from the Pacific Ocean. Arthropoda Selecta 2: 3-9.

Nye V. 2013. New species of hippolytid shrimps (Crustacea: Decapoda: Caridea: Hippolytidae) from a southwest Indian Ocean seamount. Zootaxa 3637 (2): 101-112.

https://doi.org/10.11646/zootaxa.3637.2.1

Nye V., Copley J. \& Plouviez S. 2012. A new species of Rimicaris (Crustacea: Decapoda: Caridea: Alvinocarididae) from hydrothermal vent fields on the Mid-Cayman spreading centre, Caribbean. Journal of the Marine Biological Association of the United Kingdom 92 (5): 1057-1072. https://doi.org/10.1017/S0025315411002001

Nye V., Copley J., Plouviez S. \& Van Dover C. 2013a. A new species of Lebbeus (Crustacea: Decapoda: Caridea: Hippolytidae) from the Von Damm Vent Field, Caribbean Sea. Journal of the Marine Biological Association of the United Kingdom 93 (3): 741-751. https://doi.org/10.1017/S0025315412000884

Nye V., Copley J. \& Linse K. 2013b. A new species of Eualus Thallwitz, 1892 and new record of Lebbeus antarcticus (Hale, 1941) (Crustacea: Decapoda: Caridea: Hippolytidae) from the Scotia Sea. Deep Sea Research II 92: 145-156. https://doi.org/10.1016/j.dsr2.2013.01.022

Palumbi S., Martin A., Romano S., McMillan W.O., Stice L. \& Grabowski G. 2002. The Simple Fool's Guide to PCR, version 2.0. Department of Zoology and Kewalo Marine Laboratory, University of Hawaii, Honolulu.

Paterson G.L.J., Glover A.G., Barrio Froján C.R.S., Whitaker A., Budaeva N., Chimonides J. \& Doner S. 2009. A census of abyssal polychaetes. Deep Sea Research II 56 (19-20): 1739-1746.

https://doi.org/10.1016/j.dsr2.2009.05.018

Pohle G.W. 1992. Northern range extension for the deep-sea shrimps Acanthephyra eximia, A. acutifrons and Ephyrina figueirai (Decapoda, Oplophoridae). Crustaceana 62 (3): 234-239.

https://doi.org/10.1163/156854092X00136

Poupin J. 1996. Crustacea Decapoda of French Polynesia (Astacidea, Palinuridea, Anomura, Brachyura). Atoll Research Bulletin 442: 1-114.

Available from https://biodiversitylibrary.org/page/39950783 [accessed 28 Jan. 2020].

Priede I.G. \& Froese R. 2013. Colonization of the deep sea by fishes. Journal of Fish Biology 83 (6): 1528-1550. https://doi.org/10.1111/jfb.12265

Rathbun M.J. 1902. Descriptions of new decapod crustaceans from the west coast of North America. Proceedings of the United States National Museum 24 (1272): 885-905.

Available from https://biodiversitylibrary.org/page/15782793 [accessed 28 Jan. 2020].

Rathbun M.J. 1904. Decapod Crustaceans of the Northwest Coast of North America. Harriman Alaska Expedition, with Cooperation of Washington Academy of Sciences. Doubleday, Page \& Co., New York. Available from https://biodiversitylibrary.org/page/11114942 [accessed 20 Jan. 2020].

Rathbun M.J. 1910. Decapod crustaceans collected in Dutch East India and elsewhere by Mr. Thomas Barbour in 1906-1907. Bulletin of the Museum of Comparative Zoology at Harvard College 52: 305317. Available from https://biodiversitylibrary.org/page/30093387 [accessed 28 Jan. 2020].

Savilov A.I. 1961. Ecological characteristic of benthic communities of the Sea of Okhotsk. Trudy Instituta Okeanologii AN SSSR 46: 3-84. [In Russian] 
Schiaparelli S., Ahyong S.T. \& Bowden D. 2015. Evidence of niche conservatism and host fidelity in the polar shrimp Lebbeus kiae n. sp. (Decapoda: Caridea: Thoridae) from the Ross Sea, Antarctica. Hydrobiologia 761: 45-69. https://doi.org/10.1007/s10750-015-2403-1

Sedova N.A. 2004. Distribution of shrimp larvae over the western Kamchatka shelf in 1999 and 2001. Problems of Fisheries 5 (2): 193-205. [In Russian]

Sedova N.A. \& Andronov P.U. 2013. Qualitative composition and horizontal distribution of larvae of shrimps in the northwestern Bering Sea. Bulletin of the North-East Scientific Center, Russian Academy of Sciences, Far East Branch 1: 30-38. [In Russian]

Sedova N.A. \& Grigoriev S.S. 2013. Distribution of shrimp larvae near south-eastern coast of Kamchatka during spring 2009. Bulletin of the North-East Scientific Center, Russia Academy of Sciences, Far East Branch 3: 77-86. [In Russian]

Shank T.M., Black M.B., Halanych K.M., Lutz R.A. \& Vrijenhoek R.C. 1999. Miocene radiation of deep-sea hydrothermal vent shrimp (Caridae: Bresiliidae): evidence from mitochondrial cytochrome oxidase subunit I. Molecular Phylogenetics and Evolution 13: 244-254.

https://doi.org/10.1006/mpev.1999.0642

Shearer T.L., Van Oppen M.J.H., Romano S.L. \& Worheide G. 2002. Slow mitochondrial DNA sequence evolution in the Anthozoa (Cnidaria). Molecular Ecology 11: 2475-2487.

https://doi.org/10.1046/j.1365-294x.2002.01652.x

Sites J.W. \& Marshall J.C. 2004. Operational criteria for delimiting species. Annual Review of Ecology, Evolution and Systematics 35: 199-227. https://doi.org/10.1146/annurev.ecolsys.35.112202.130128

Smith S.I. 1885. On some new or little known Decapoda Crustacea from recent Fish Commission dredgings off the east coast of the United States. Proceedings of the United States National Museum 7: 493-511. Available from https://biodiversitylibrary.org/page/7306287 [accessed 28 Jan. 2020].

Spence Bate C.S. 1888. Report on the Crustacea Macrura collected by H.M.S. Challenger during the years 1873-1876. Report on the Scientific Results of the Voyage of H.M.S. Challenger during the Years 1873-76, Zoology 24: i-xc, 1-942. Available from https://biodiversitylibrary.org/page/2020399 [accessed 20 Jan. 2020].

Spiridonov V.A., Petryashov V.V. \& Marin I.N. 2013. Order Decapoda. In: Sirenko B.I. (ed.) Check-list of Species of Free-living Invertebrates of the Russian Far Eastern Seas. Issledovaniya Fauny Morei 75 (83): 116-118. Zoological Institute of Russian Academy of Sciences, St. Petersburg.

Squires H.J. 1990. Decapod Crustacea of the Atlantic coast of Canada. Canadian Bulletin of Fisheries and Aquatic Sciences 221: 1-532.

Tiefenbacher L. 1991. Anmerkungen zu einigen mesopelagischen Garnelen und ihrer Verbreitung in den Gewässern der westlichen Antarktis (Crustacea Decapoda Natantia). Spixiana 14 (2): 153-158. Available from https://biodiversitylibrary.org/page/32912164 [accessed 3 Feb. 2020].

Tiefenbacher L. 1994. Decapode Crustaceen aus westantarktischen Gewässern gesammelt von der R.V. "John Biscoe", Reise 11. Spixiana 17 (1): 13-19.

Available from https://biodiversitylibrary.org/page/28201291 [accessed 27 Jan. 2020].

Titus B.M., Daly M, Hamilton N., Beruman M. \& Baeza J.A. 2018. Global species delimitation and phylogeography of the circumtropical "sexy shrimp" Thor amboinensis reveals a cryptic species complex and secondary contact in the Indo-West Pacific. Journal of Biogeography 45: 1275-1287. https://doi.org/10.1111/jbi.13231

Urita T. 1942. Decapod crustaceans from Saghalien, Japan. Bulletin of the Biogeographical Society of Japan 12: 1-78. 
Uschakov P.V. 1953. Fauna of the Sea of Okhotsk and its Environment. USSR Academy of Sciences, Moscow. [In Russian]

Van Dover C.L., Humphris S.E., Fornari D., Cavanaugh C.M., Collier R., Goffredi S.K., Hashimoto J., Lilley M.D., Reysenbach A.L., Shank T.M., Von Damm K.L., Banta A., Gallant R.M., Gotz D., Green D., Hall J., Harmer T.L., Hurtado L.A., Johnson P., McKiness Z.P., Meredith C., Olson E., Pan I.L., Turnipseed M., Won Y., Young C.R. \& Vrijenhoek R.C. 2001. Biogeography and ecological setting of Indian Ocean hydrothermal vents. Science 294 (5543): 818-823.

https://doi.org/10.1126/science.1064574

Vereshchaka A.L. 1997. A new family for a deep-sea caridean shrimp from North Atlantic hydrothermal vents. Journal of the Marine Biological Association of the United Kingdom 77 (2): 425-438.

https://doi.org/10.1017/S0025315400071770

Vereshchaka A.L., Kulagin D.N. \& Lunina A.A. 2015. Phylogeny and new classification of hydrothermal vent and seep shrimps of the family Alvinocarididae. PLoS One 10 (7): e0129975.

https://doi.org/10.1371/journal.pone.0129975

Vinogradov L.G. 1947. Decapod crustaceans of the Sea of Okhotsk. Izvestija TINRO 25: 67-124. [In Russian, with English summary]

Vinogradov L.G. 1950. Identification Keys for Shrimps, Crayfish and Crabs of the Russian Far East. Izvestiya TINRO 33: 179-358. [In Russian, with English summary]

Wasmer R.A. 1986. Pelagic shrimps of the family Oplophoridae (Crustacea: Decapoda) from the Pacific sector of the Southern Ocean: USNS Eltanin Cruises 10, 11, 14-16, 19-21, 24, and 25. In: Kornicker L.S. (ed.) Biology of the Antarctic Seas XVII 44: 29-68.

Watabe H. \& Hashimoto J. 2002. A new species of the genus Rimicaris (Alvinocarididae: Caridea: Decapoda) from the active hydrothermal vent field, "Kairei Field," on the Central Indian Ridge, the Indian Ocean. Zoological Science 19 (10): 1167-1174. https://doi.org/10.2108/zsj.19.1167

Wharton D.N., Jinks R.N., Herzog E.D., Battelle B.A., Kass L., Renninger G.H. \& Chamberlain S.C. 1997. Morphology of the eye of the hydrothermal vent shrimp, Alvinocaris markensis. Journal of the Marine Biological Association of the United Kingdom 77 (4): 1097-1108.

https://doi.org/10.1017/S0025315400038650

Whiting M.E., Carpenter J.C, Wheeler Q.D. \& Wheeler W.C. 1997. The Strepsiptera problem: phylogeny of the holometabolous insect orders inferred from 18S and 28S ribosomal DNA sequences and morphology. Systematic Biology 46 (1): 1-68. https://doi.org/10.1093/sysbio/46.1.1

Wicksten M.K. 2002. Midwater decapods of the northeastern Pacific. Contributions to the Study of East Pacific Crustaceans 1: 127-144.

Wicksten M.K. 2010. Lebbeus laurentae: a replacement name for Lebbeus carinatus de Saint Laurent, 1984 (Decapoda: Caridea: Hippolytidae) and a redescription of the species. Proceedings of the Biological Society of Washington 123 (3): 196-203. https://doi.org/10.2988/10-05.1

Wicksten M.K. \& Mendez M.M. 1982. New records and new species of the genus Lebbeus (Caridea: Hippolytidae) in the eastern Pacific Ocean. Bulletin of the Southern California Academy of Sciences 81: 106-120. Available from https://biodiversitylibrary.org/page/34406805 [accessed 27 Jan. 2020].

Wicksten M.K., De Grave S., France S. \& Kelley C. 2017. Presumed filter-feeding in a deep-sea benthic shrimp (Decapoda, Caridea, Stylodactylidae), with records of the deepest occurrence of carideans. ZooKeys 646: 17-23. https://doi.org/10.3897/zookeys.646.10969 
Williams A.B. 1987. More records for shrimps of the genus Rimicaris (Decapoda, Caridea, Bresiliidae) from the Mid-Atlantic Rift. Journal of Crustacean Biology 7 (1): 105. https://doi.org/10.1163/193724087X00081

Williams A.B. 1988. New marine decapod crustaceans from waters influenced by hydrothermal discharge, brine and hydrocarbon seepage. Fishery Bulletin 86: 263-287.

Williams A.B. \& Rona P.A. 1986. Two new caridean shrimps (Bresiliidae) from a hydrothermal field on the Mid-Atlantic Ridge. Journal of Crustacean Biology 6 (3): 446-462.

https://doi.org/10.1163/193724086X00299

Wolff T. 1970. The concept of the hadal or ultra-abyssal fauna. Deep Sea Research 17 (6): 983-1003. https://doi.org/10.1016/0011-7471(70)90049-5

Yaldwyn J.C. \& Webber W.R. 2011. Annotated checklist of New Zealand Decapoda (Arthropoda: Crustacea). Tuhinga 22: 171-272.

Zakšek V., Sket B. \& Trontelj P. 2007. Phylogeny of the cave shrimp Troglocaris: evidence of a young connection between Balkans and Caucasus. Molecular Phylogenetics and Evolution 42: 223-235. https://doi.org/10.1016/j.ympev.2006.07.009

Zarenkov N.A. 1960. Observations about some decapod Crustacea from the Sea of Okhotsk and Bering Sea. Trudy Instituta Okeanologii 34: 343-350. [In Russian]

Zarenkov N.A. 1965. Revision of the genera Crangon Fabricius and Sclerocrangon G.O. Sars (Decapoda, Crustacea). Zoologicheskyi Zhurnal 44: 1761-1775. [In Russian]

Zarenkov N.A. 1968. Crustacean Decapoda collected by the Soviet Antarctic expeditions in the Antarctic and antiboreal regions. Biological Reports of the Soviet Antarctic Expedition (1955-1958) 4: 153-201.

Zarenkov N.A. 1976. On the fauna of decapods of the waters adjacent to South America. Byulleten' Moskovskogo Obshchestva Ispytatelei Prirody, Otdel Biologicheskii 5: 8-18. [In Russian]

Zhang J., Sun Q.-I., Luan Z.-D., Lian C. \& Sun L. 2017. Comparative transcriptome analysis of Rimicaris sp. reveals novel molecular features associated with survival in deep-sea hydrothermal vent. Scientific Report 7: e2000. https://doi.org/10.1038/s41598-017-02073-9

Manuscript received: 1 September 2019

Manuscript accepted: 8 November 2019

Published on: 13 February 2020

Topic editor: Rudy Jocqué

Desk editor: Danny Eibye-Jacobsen

Printed versions of all papers are also deposited in the libraries of the institutes that are members of the EJT consortium: Muséum national d'histoire naturelle, Paris, France; Meise Botanic Garden, Belgium; Royal Museum for Central Africa, Tervuren, Belgium; Royal Belgian Institute of Natural Sciences, Brussels, Belgium; Natural History Museum of Denmark, Copenhagen, Denmark; Naturalis Biodiversity Center, Leiden, the Netherlands; Museo Nacional de Ciencias Naturales-CSIC, Madrid, Spain; Real Jardín Botánico de Madrid CSIC, Spain; Zoological Research Museum Alexander Koenig, Bonn, Germany; National Museum, Prague, Czech Republic. 
Appendix 1. List of additional nucleotide sequences (alignments) of COI mtDNA used for moleculargenetic analysis.

\begin{tabular}{|c|c|}
\hline Taxon & GenBank (NCBI) reference \\
\hline Lebbeus antarcticus & KC494749, KC494750, KC494751, KC494752 \\
\hline Lebbeus carinatus & AF125421, AF125422 \\
\hline Lebbeus formosus & MK409684 \\
\hline Lebbeus groenlandicus & $\begin{array}{l}\text { DQ882084, FJ581737, MG312804, MG315672, } \\
\text { MG321028, MH242822 }\end{array}$ \\
\hline Lebbeus java & MK409683 \\
\hline Lebbeus kiae & KT187241, KT187242, KT187243 \\
\hline Lebbeus polaris & $\begin{array}{l}\text { FJ581738, FJ581739, HM425371, HQ966810, } \\
\text { KP759419, KP759420, MG312952, MG315175, } \\
\text { MG317301, MG317885, MG318898, MG319773, } \\
\text { MG319844, MG319853, MG319864, MG320139, } \\
\text { MG320699, MG321050, MG935131 }\end{array}$ \\
\hline Lebbeus virentova & JQ837265, KJ566966 \\
\hline Eualus amandae & KC494753, KC494755, KC494757 \\
\hline Eualus avinus & DQ882064, DQ882065 \\
\hline Eualus barbatus & DQ882067, DQ882068, DQ882069 \\
\hline Eualus biunguis & DQ882071, DQ882072, DQ882074 \\
\hline Eualus fabricii & $\begin{array}{l}\text { FJ581627, FJ581628, MG313581, MG315523, } \\
\text { MG319600 }\end{array}$ \\
\hline Eualus gaimardii & $\begin{array}{l}\text { DQ882075, FJ581629, GU680599, JQ305958, KJ833719, } \\
\text { MG311508, MG314000, MG316319, MG316770 }\end{array}$ \\
\hline Eualus macilentus & FJ581633, FJ581634, FJ58163 \\
\hline Eualus occultus & MG935395 \\
\hline Eualus pusiolus & KT209086, KT209346, KT209527, MG935120 \\
\hline Eualus subtilis & MH242750, МH242751 \\
\hline Eualus suckleyi & DQ882076, DQ882077, MH242752 \\
\hline Spirontocaris arcuata & KJ833723 \\
\hline Spirontocaris holmesi & DQ882153, KJ833721, MG314460 \\
\hline Spirontocaris lamellicornis & $\begin{array}{l}\text { DQ882155, DQ882157, MG317259, MH242976, } \\
\text { MH242977 }\end{array}$ \\
\hline Spirontocaris lilljeborgii & $\begin{array}{l}\text { FJ581902, FJ581903, KT208836, KT209558, } \\
\text { MG934951, MG935142 }\end{array}$ \\
\hline Spirontocaris ochotensis & 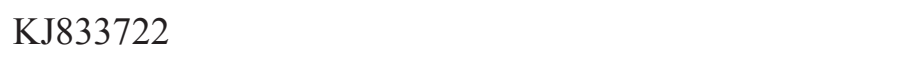 \\
\hline Spirontocaris phippsi & DQ882159, MG312751, MG316040 \\
\hline Spirontocaris prionota & MH242978 \\
\hline Spirontocaris sica & DQ882160, DQ882162, KJ833724 \\
\hline Spirontocaris snyderi & KJ833720 \\
\hline Spirontocaris spinus & $\begin{array}{l}\text { DQ882163, FJ581908, FJ581909, FJ581910, MG312738, } \\
\text { MG313477, MG314259 }\end{array}$ \\
\hline
\end{tabular}


Thor amboinensis

Thor manningi

Thoralus cranchii

Heptacarpus sitchensis

Heptacarpus tenuissimus

Heptacarpus tridens

Heptacarpus sp.

\section{Outgroup}

Alcyonohippolyte commensalis Alcyonohippolyte dossena Alcyonohippolyte tubiporae

Hippolyte bifidirostris

Hippolyte catagrapha

Hippolyte clarki

Hippolyte edmondsoni

Hippolyte holthuisi

Hippolyte inermis

Hippolyte leptocerus

Hippolyte niezabitowskii

Hippolyte obliquimanus

Hippolyte pleuracanthus

Hippolyte prideauxiana

Hippolyte sapphica

Hippolyte varians

Hippolyte ventricosa

Hippolyte williamsi

Hippolyte zostericola
GQ260961, JQ180245, KU201280, KU201284,

KU496552, KX926338, KX926345, KX926393,

MF378785, MF378797, MF378800, MF378803,

MF378804, MF378805, MF378806, MF378807,

MF378808, MF378811, MF378815, MF378817,

MF378819, MF378820, MF378821, MF378844,

MF378866, MF378880, MF378919, MF378921,

MF378964, MF378987, MF378991, MF379021,

MF379022

KX589004

KJ841675, KT209005, KT209433

MH242790

MH242791

MH242792

MF745573, MG936583

KX589001

KX589002

KX589000

KX588969

KX588970

KX588971, KX588972

KX588973, KX588974

KX588978

KX588976, KX588977

KX588981, KX588982

KX588985

JF794718, JF794734

KX588986, KX588987

KX588989

KX588990, KX588991

KT208694, KX588996, MG935168

KX588997, KX588998

JF794738, KX588999

KU906017, KU906112 